\title{
Organic compatible solutes of halotolerant and halophilic microorganisms Mary F Roberts*
}

\author{
Address: Merkert Chemistry Center, Boston College, 2609 Beacon Street, Chestnut Hill, MA 02465, USA \\ Email: Mary F Roberts* - mary.roberts@bc.edu \\ * Corresponding author
}

Published: 04 August 2005

Saline Systems 2005, I:5 doi:10.1186/1746-1448-I-5

This article is available from: http://www.salinesystems.org/content/I/I/5

(C) 2005 Roberts; licensee BioMed Central Ltd.

This is an Open Access article distributed under the terms of the Creative Commons Attribution License (http://creativecommons.org/licenses/by/2.0), which permits unrestricted use, distribution, and reproduction in any medium, provided the original work is properly cited.
Received: 03 June 2005
Accepted: 04 August 2005

\begin{abstract}
Microorganisms that adapt to moderate and high salt environments use a variety of solutes, organic and inorganic, to counter external osmotic pressure. The organic solutes can be zwitterionic, noncharged, or anionic (along with an inorganic cation such as $\mathrm{K}^{+}$). The range of solutes, their diverse biosynthetic pathways, and physical properties of the solutes that effect molecular stability are reviewed.
\end{abstract}

A dynamic and important property of cells is their ability to rapidly adapt to changes in external media, for example, increasing $\mathrm{NaCl}$. To adjust to increased external $\mathrm{NaCl}$, cells in all three kingdoms accumulate a variety of small molecules in the cytoplasm to counteract the external osmotic pressure. Inorganic cations $\left(\mathrm{K}^{+}\right.$and in some cells $\mathrm{Na}^{+}$) are often key players in osmotic balance and the osmotic response. However, the diverse collection of organic solutes that organisms accumulate in response to salt stress (also termed osmolytes) is particularly intriguing. Cataloging the occurrence of different molecules and understanding their biosynthesis and regulation by external osmotic pressure have been active areas of research. Studies show that the accumulation of solutes has another role along with osmotic balance. Many osmolytes have been shown to increase the stability of proteins. They appear to act as chemical chaperones in cells, and the mechanism of this stabilization can provide insights into protein folding. The thermostabilizing role of osmolytes has also been exploited for various biotechnology purposes. The aim of this review is an examination of the chemical and biological scope of osmolytes in a wide range of halotolerant and halophilic organisms with an overview of experiments that address why these types of solutes have been naturally selected for osmotic balance. Also included is a brief summary of the biotechnological uses of these organic osmolytes.

The types of organic molecules used for osmotic balance include polyols and derivatives, sugars and derivatives, amino acids and derivatives, betaines, and ectoines and occasionally peptides suitably altered to remove charges [1]. As a general rule of thumb, bacteria and eukaryotes usually accumulate neutral compatible solutes whereas archaea prefer negatively charged solutes [2,3]. Interestingly, archaea tend to modify many of the same neutral or zwitterionic solutes accumulated by eukaryotes or bacteria to make them negatively charged. Osmolytes can either be synthesized by the cell or transported into the cell from the medium. A key feature of these molecules is that they do not inhibit overall cellular functions, although they may modulate individual enzyme activities. This behavior led to labeling them as 'compatible solutes' [4]. Their accumulation helps to maintain turgor pressure, cell volume, and concentration of electrolytes all important elements for cell proliferation. It is thought 
that initial events that trigger osmolyte accumulation could include ion channels or other transmembrane proteins sensing differences in external and internal salt concentration, cell volume changes, and/or turgor pressure changes. However, except for transporters, how these physical changes are translated to increased osmolyte synthesis is not known.

\section{Identification of Osmolytes}

Although osmolytes tend to occur at high intracellular concentrations, they do not have unique chromophores and were not considered in much detail and in most cases even identified until high resolution NMR spectroscopy became a routine analytical method. From the 1970s onward, a variety of NMR approaches have been used to identify the organic solutes accumulated by halotolerant and halophilic organisms. Early natural abundance ${ }^{13} \mathrm{C}$ NMR studies of cell extracts identified novel solutes, such as ectoine [5], several $\beta$-amino acids [6-8], and di-myoinositol-1,1'-phosphate (DIP), the last associated with hyperthermophiles $[9,10]$. More recent methods using ${ }^{1} \mathrm{H}$ NMR and two-dimensional experiments have significantly increased the sensitivity of solute detection [11]. ${ }^{1} \mathrm{H}$ NMR methodology can also be used to detect and quantify osmolytes in cell cultures without extraction [12]. Other analytical methods such as HPLC have been used, often to quantify specific solutes as long as an appropriate detection method is available. Refractive index detection is the most general [13], but specific classes of molecules can be derivatized for rapid and sensitive detection (e.g., chromophores added to solutes containing free amino groups [14]). More recent advances have improved on the sensitivity of these other assays. For example, the combination of anion-exchange chromatography and pulse amperometric detection is a very sensitive method that can detect osmolytes such as ectoine after hydrolytic cleavage of the pyrimidine ring [15]. The methodology is sufficiently sensitive that it can be used to screen colonies on agar for solutes.

Organic osmolytes fall into three general chemical categories: (i) zwitterionic solutes, (ii) noncharged solutes, and (iii) anionic solutes. Structures of these molecules and their occurrence in halotolerant and halophilic microorganisms are presented in Figures 1,2,3,4. Intertwined with these organic solutes are $\mathrm{K}^{+}$and $\mathrm{Na}^{+}$which also contribute to osmotic balance in cells.

\section{A. Zwitterionic Solutes}

Free polar amino acids in cells might be expected to play a role in osmotic balance. However, neutral amino acids are not accumulated to high concentrations, presumably because they are intermediates in protein biosynthesis. High and varying concentrations of these compounds could affect diverse cell pathways. Instead, many bacterial and archaeal cells synthesize and accumulate a few zwitterionic molecules derived from amino acids as compatible solutes. Structures of these solutes and where they are found are presented in Figure 1.

\section{Betaine}

This ubiquitous solute, glycine with the primary amine methylated to form a quaternary amine, is found in halophilic bacteria of diverse phylogenetic affiliation [16]. In most cells where it is accumulated as an osmolyte, the betaine is actively transported from complex medium. Betaine concentrations vary with external $\mathrm{NaCl}$. For example, Imhoff and Rodriguez-Valera [16] showed that for the eight halophiles examined, the average betaine concentrations in 3,10 and $20 \% \mathrm{NaCl}(0.51,1.7$ and $3.4 \mathrm{M})$ were $0.21 \pm 0.2,0.65 \pm 0.06$, and $0.97 \pm 0.09 \mathrm{M}$. A number of methanogens have also been observed to accumulate betaine when grown in rich medium [17]. In contrast to the large number of bacteria that transport betaine into the cell for use as an osmolyte, there are only a few bacteria (e.g., Actinopolyspora halophila and Halomonas elongata) and one methanogen (Methanohalophilus portucalensis FDF1) that are able to synthesize betaine either by oxidation of choline or methylate of glycine [18-20].

\section{Ectoine and hydroxyectoine}

Ectoine, a cyclic tetrahydropyrimidine (1,4,5,6-tetrahydro-2-methyl-4-pyrimidinecarboxylic acid) can almost be considered a marker for halophilic bacteria. As shown in Figure 1, it is synthesized by a wide range of bacteria, both halotolerant and halophilic varieties. This solute was first detected in the halophilic, phototrophic Halorhodospora halochloris [5]. The intracellular ectoine concentration was shown to increase with increased extracellular $\mathrm{NaCl}$. Screens of a number of microorganisms have shown that ectoine is the major osmolyte in aerobic chemoheterotrophic bacteria [1]. It is also the major solute in bacterial strains isolated from alkaline, hypersaline Mono Lake [21]. More recently it has also been observed in the moderately halophilic methylotrophic bacteria Methylarcula marina, M. terricola, and Methylophaga sp. [22,23]. A variant of this solute, hydroxyectoine, has been detected in halotolerant Sporosarcina pasteurii grown in high osmolarity medium [24].

Growth conditions have been shown to affect the intracellular ectoine pool. For example, in halotolerant Brevibacterium sp., the size of the intracellular ectoine pool depends not only on the external salt concentration but on the type of carbon source and aeration level [25]. Ectoine accumulation can also depend on growth stage. In Chromohalobacter israelensis (formerly Bacterium Ba1), ectoine only accumulated when the cells were grown in greater than $0.6 \mathrm{M} \mathrm{NaCl}$, and only in exponentially growing cells [26]. Some microorganisms, e.g., Brevibacterium 


\begin{tabular}{|c|c|}
\hline Zwitterionic solutes: & Occurrence: \\
\hline 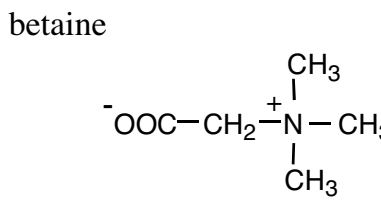 & $\begin{array}{l}\text { Halotolerant: Thioalkalivibrio versutus; } \\
\text { Actinopolyspora sp. } \\
\text { Halophilic: Actinopolyspora halophila; Halorhodospira halochloris } \\
\text { Methanohalophilus portulcalensis FDF1; Methanosarcina } \\
\text { thermophila; Synechococcus sp. DUN } 52\end{array}$ \\
\hline ectoine & $\begin{array}{l}\text { Halotolerant: Sporosarcina pasteurii.; Brevibacterium epidermidis; } \\
\text { Thioalkalimicrobium aerophilum; Vibrio cholerae and V. costociola } \\
\text { Halophilic: Chromohalobacter israelensis; Chromohalobacter } \\
\text { salexigens; Halorhodospira halochloris; Halomonas elongata, H. } \\
\text { variabilis and phylogenetically related organisms; Methylarcula } \\
\text { marina and M. terricola; Methylophaga alcalica and Methylophaga } \\
\text { natronic; aerobic, halophilic isolates from Mono Lake }\end{array}$ \\
\hline hydro & Halophilic: Halomonas elongata; Nocardiopsis halophila \\
\hline $\begin{array}{c}\mathrm{N} \gamma \text {-acetyldiaminobutyrate } \\
\mathrm{CH}_{3} \mathrm{C}-\mathrm{NH}-\mathrm{CH}_{2}-\mathrm{CH}_{2}-\mathrm{CHC} \\
+\mathrm{NH}_{3}\end{array}$ & Halotolerant: Halomonas elongata CHR63 \\
\hline $\mathrm{N} \varepsilon$-acetyl- $\beta$-lysine & $\begin{array}{l}\text { Halotolerant: Methanosarcina thermophila; Methanothermococcus } \\
\text { thermolithotrophicus; Methanosarcina mazei Gö1 } \\
\text { Halophilic: Methanohalophilus portucalensis FDF1; } \\
\text { Methanohalophilus Z7302 }\end{array}$ \\
\hline$\beta$-glutamine & Halophilic: Methanohalophilus portucalensis FDF1 \\
\hline
\end{tabular}

\section{Figure I}

Zwitterionic organic osmolytes detected in bacteria and archaea.

epidermidis, can also metabolize ectoine [27], perhaps a useful trait if external salt concentrations decrease. In that halotolerant organism, ectoine accumulation occurs only with salt stress, not sugar stress.
The ability to accumulate ectoine can give an organism an ecological advantage. High-osmolarity-adapted Vibrio cholerae cells accumulate ectoine and betaine and out grow non-adapted cells [28]. This has implications for $V$. 


\begin{tabular}{|c|c|}
\hline Uncharged solutes: & Occurrence: \\
\hline -glucosylglycerol & $\begin{array}{l}\text { Halotolerant: marine \&freshwater cyanobacteria: Synechocystis sp. } \\
\text { Microcystis firma; phototrophic eubacteria: Rhodovulum } \\
\text { sulfidophilum; Pseudomonas mendocina and P.pseudoalcaligenes; } \\
\text { Stenotrophomonas }\end{array}$ \\
\hline a-mannosylglyceramide & Halotolerant: Rhodothermus marinus (R. obamensis) \\
\hline trehalose & $\begin{array}{l}\text { Halotolerant: Pyrobaculum aerophilum; Sulfolobus solfataricus and } \\
\text { S. ambivalens; Thermoproteus tenax; Thermoplasma acidophilum } \\
\text { Halophilic: Actinopolyspora halophila; Chromohalobacter } \\
\text { israelensis; Desulfovibrio halophilus; Rhodothermus obamensis; } \\
\text { Natrialba magadii }\end{array}$ \\
\hline sucrose & $\begin{array}{l}\text { Haloterant: diverse cyanobacteria (Synechocystis sp. strain PCC } \\
6803 \text {, Anabaena spp.) and proteobacteria }\end{array}$ \\
\hline$\sum=0$ & Halophilic: Ectothiorhodospira mobilis (marismortui) \\
\hline N-acetylglutaminylglutamine amide & $\begin{array}{l}\text { Halotolerant: Sinorhizobium meliloti; Rhizobium leguminosarum; } \\
\text { Pseudomonas aeruginosa } \text { PAO1 } \\
\text { Halophilic: purple sulfur bacteria }\end{array}$ \\
\hline
\end{tabular}

\section{Figure 2}

Uncharged organic osmolytes detected in bacteria and archaea. 


\begin{tabular}{|l|l|}
\hline Onionic solutes (carboxylates): & Ocurrence: \\
\hline Many halotolerant bacteria and methanogens \\
Halophilic: Halomonas elongata; Methanohalophilus portucalensis \\
FDF1; Halobacterium sp. $\mathrm{NRC}$-1 and H. salinarum
\end{tabular}

Figure 3

Anionic organic osmolytes containing carboxylates that have been detected in bacteria and archaea.

cholerae population dynamics when seawater and freshwater and their attendant microbes mix.

\section{NE-acetyl- $\beta$-lysine and $\beta$-glutamine}

Methanogens have a notably different strategy than many other organisms in that they accumulate several $\beta$-amino acids for osmotic balance. These solutes provide an excellent strategy for producing a compatible solute since $\beta$ amino acids are not incorporated into proteins or other macromolecules. At high external $\mathrm{NaCl}(>1 \mathrm{M})$, two zwitterionic $\beta$-amino acids have been shown to accumulate in response to external $\mathrm{NaCl}$. $\mathrm{N} \varepsilon$-acetyl- $\beta$-lysine has been 


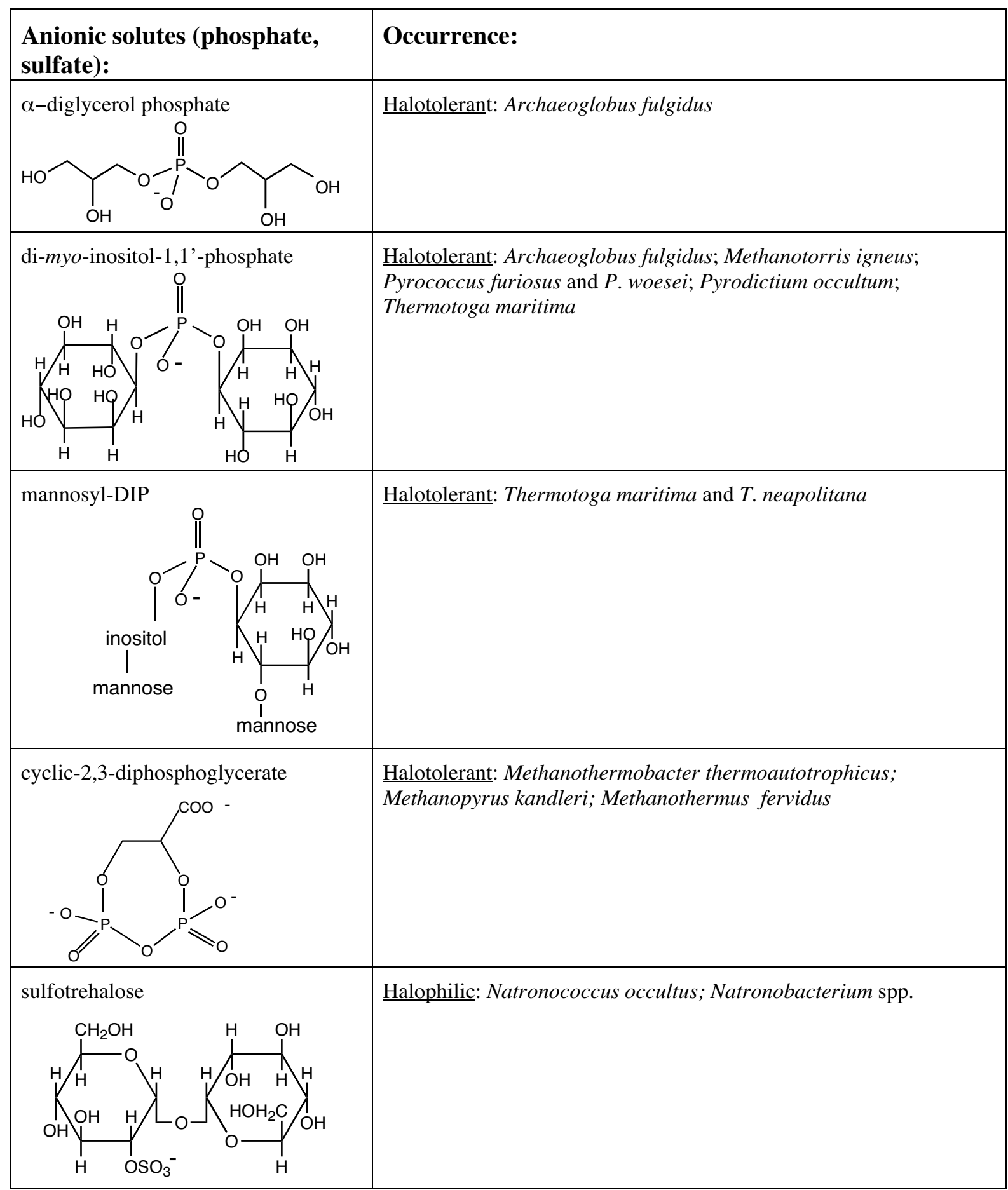

Figure 4

Anionic organic osmolytes containing phosphate or sulfate moieties that have been detected in bacteria and archaea. 
detected in a wide range of mesophilic and a few thermophilic methanogens $[7,29-31]$. $\beta$-Glutamine has been detected in Methanohalophilus species where it is synthesized and accumulated along with $\mathrm{N} \varepsilon$-acetyl- $\beta$-lysine and betaine [8]. ${ }^{13} \mathrm{C}$-pulse $/{ }^{12} \mathrm{C}$-chase and ${ }^{15} \mathrm{~N}$-pulse/ $/{ }^{14} \mathrm{~N}$-dilution NMR experiments can be carried out where cells are grown in the presence of an NMR-active isotope (typically ${ }^{13} \mathrm{CO}_{2}$ or ${ }^{15} \mathrm{NH}_{4} \mathrm{Cl}$ ) for some time. The labeled compound is then removed or significantly diluted with unlabeled material $\left({ }^{12} \mathrm{CO}_{2}\right.$ or $\left.{ }^{14} \mathrm{NH}_{4} \mathrm{Cl}\right)$. Loss of the NMR-active isotope then monitors the turnover of these $\beta$-amino acid solute pools in the cells. Both $N \varepsilon$-acetyl- $\beta$-lysine and $\beta$ glutamine exhibit little if any turnover in cells as expected if these are used only for osmotic balance [30,31].

\section{B. Noncharged solutes}

Few molecules that are polar but lack any formal charges have been identified as osmolytes in halophilic bacteria, although they are well represented in eukaryotes. For example, glycerol is prevalent as an osmolyte in marine and halophilic Dunaliella [32,33]. Glycerol accumulation is also a characteristic of halotolerant yeast Debaryomyces hansenii as well as the black yeast Hortea werneckii, and adaptation of this eukaryotic organism to high $\mathrm{NaCl}$ requires glycerol accumulation [33]. Myo-inositol, another polyol, is used as an osmolyte in several eukaryotes. Neither of these polar noncharged solutes has been identified as an osmolyte in bacteria or archaea (or associated with halophiles). However, negatively charged derivatives of both glycerol and inositol are accumulated by archaea. The few uncharged solutes that are used by halotolerant bacteria and archaea include several carbohydrates and an amino acid/dipeptide modified to neutralize all charged groups (Figure 2).

\section{Carbohydrates}

Few carbohydrates are used for osmotic balance, perhaps because those with a reducing end are chemically reactive, and in a sea of proteins these noncharged solutes would be likely to react with surface amino groups. To avoid this, the reactive end of the sugar forms a glycosidic bond with a small neutral molecule, either glycerol or glyceramide. The neutral derivatized sugars glucosylglycerol and $\alpha$ mannosylglyceramide [34] have been detected in a few bacteria (Figure 2). $\alpha$-Glucosylglycerol is accumulated by a member of the Proteobacteria, Stenotrophomonas [35]. This organism has a large number of potential biotechnology uses (many based on its ability to use uncommon carbon sources), one of which is the production of glucosylglycerol. $\alpha$-Mannosylglyceramide is accumulated in Rhodothermus marinus [34].

The non-reducing glucose disaccharide trehalose is used by organisms to counteract drying, but it also serves as an osmolyte. In Actinopolyspora halophila trehalose represents
$15 \% \mathrm{w} / \mathrm{v}$ in cells grown in $24 \% \mathrm{w} / \mathrm{v} \mathrm{NaCl}$ [36]. However, in some cells, its accumulation is preferred at lower $\mathrm{NaCl}$. For examples, in Chromohalobacter israelensis, trehalose is only an important solute when the cells are grown with $<0.6 \mathrm{M}$ external $\mathrm{NaCl}[26]$. In the sulfate-reducing bacterium Desulfovibrio halophilus, trehalose is the major osmolyte. When grown in $15 \%(2.5 \mathrm{M}) \mathrm{NaCl}$ in the absence of a source of betaine, the cells accumulated $8 \mu \mathrm{mol}$ trehalose $/ \mathrm{mg}$ protein and $\sim 2.5 \mu \mathrm{mol} \mathrm{K}^{+} / \mathrm{mg}$ protein [37].

Disaccharides without modifications, notably sucrose, can be transported by some halotolerant and halophilic organisms, and this can enhance growth in higher $\mathrm{NaCl}$. Sucrose is synthesized in cyanobacteria and proteobacteria $[38,39]$ where it is usually associated with lower salt tolerance strains. Synechocystis sp. strain PCC 6803 tolerates up to $1.2 \mathrm{M} \mathrm{NaCl}$. In those cells, the sucrose is a minor solute (glucosylglycerol is the major osmolyte). However, the sucrose is critical for stationary phase survival under salt stress conditions [40]. This observation was rationalized by proposing that the sucrose could regulate metabolic pathways that are active under the nutritional stress conditions of stationary phase [40].

While it is rarely synthesized in bacteria, sucrose is a major osmoprotectant in plants, and synthesis of sucrose is similar in both cyanobacteria and plants. There are two distinct pathways. In freshwater and marine cyanobacteria, sucrose is synthesized synthesized from fructose-6-phosphate and a sugar nucleotide (UDP-glucose) in two steps using sucrose phosphate synthase and sucrose-phosphate phosphatase [41]. Filamentous cyanobacteria (e.g., Anabaena sp.) use a different pathway, sucrose synthase, which reversibly converts fructose and ADP-glucose (or UDP-glucose) to sucrose [42]. Since sucrose-synthesizing enzymes cannot be identified in other bacteria or archaea, it is thought that sucrose synthesis in eukaryotes was acquired by endosymbiotic cyanobacteria that were the ancestors of chloroplasts [43].

\section{Uncharged Amino Acids and Peptides}

Two solutes in this class have been identified as osmolytes: (i) a carboxamine, and (ii) an acetylated neutral glutamine dipeptide. In both solutes, modifications mask the charged $\alpha$-amino and $\alpha$-carboxyl groups. $N$ - $\alpha$-Carbamoyl-L-glutamine 1-amide, an unusual amino acid derivative, is accumulated by halophilic phototrophic bacterium Ectothiorhodospira marismortui (also known as Ectothiorhodospira mobilis) [44]. The dipeptide Nacetylglutaminylglutamine amide is synthesized by several halophilic purple sulfur bacteria $[45,46]$.

\section{Organic anions}

Cells have a negative potential inside and often quite high intracellular $\mathrm{K}^{+}$. Negatively charged solutes could serve to 
balance high intracellular $\mathrm{K}^{+}$as well as counteract osmotic pressure. Indeed, at lower external $\mathrm{NaCl}$, many bacteria (including H. elongata which also synthesizes ectoine) and archaea use L- $\alpha$-glutamate as an osmolyte. In methanogens, high $\mathrm{NaCl}$ often causes the cells to switch from anionic glutamate isomers to the zwitterionic solute $\mathrm{N} \varepsilon$ acetyl- $\beta$-lysine for osmotic balance [29,31]. Anionic solutes used by bacteria and archaea for osmotic balance can have a carboxylate supply the negative charge (Table 3 ) or contain phosphate or sufate groups (Figure 4).

\section{I. $\beta$-Glutamate}

Methanogens tend to accumulate $\beta$-glutamate as well as $\alpha$-glutamate for osmotic balance. ${ }^{13} \mathrm{C}$-pulse $/{ }^{12} \mathrm{C}$-chase NMR experiments that monitor solute turnover for $\alpha$ - and $\beta$-glutamate have shown that the $\alpha$-glutamate pool is metabolized and replenished while the $\beta$-amino acid pool is relatively static, hence it is an ideal compatible solute $[30,31,47,48]$. In Methanothermococcus thermolithotrophicus, both the $\alpha$ - and $\beta$-glutamate levels increase with increasing external $\mathrm{NaCl}[49]$. However, there appears to be a threshold for the glutamates in this organism. The negatively charged glutamates are accumulated when the external $\mathrm{NaCl}$ is less than $1 \mathrm{M}$. In that regime, the total intracellular glutamates occur at concentrations comparable to the intracellular $\mathrm{K}^{+}$. Above $1 \mathrm{M} \mathrm{NaCl}$, zwitterionic $\mathrm{N} \varepsilon$-acetyl- $\beta$-lysine becomes the major solute $[31,50]$. The accumulation of the zwitterions at high $\mathrm{NaCl}$ could indicate that it is now energetically too costly to increase $\mathrm{K}^{+}$ and hence the anionic glutamates that aid in neutralizing much of the $\mathrm{K}^{+}$are not needed. In support of this are observations in $M$. thermolithotrophicus that within $30 \mathrm{~min}$ of switching cells from 0.67 to $1.4 \mathrm{M} \mathrm{NaCl}$, both $\mathrm{K}^{+}$and glutamate concentrations increase transiently then later decrease as the zwitterion is eventually synthesized [48].

While most studies identifying $\beta$-glutamate have concentrated on methanogens, this solute has been detected in a few bacteria as well. For example, it has been detected in the Gram-positive organism Nocardiopsis halophila, which also accumulates the zwitterionic hydroxyectoine [51].

\section{2. $\beta$-Hydroxybutyrate and derivatives}

Soluble poly- $\beta$-hydroxybutyrates, normally used as carbon reservoirs in cells, have been detected in moderate concentrations in a number of organisms, including Methylarcula marina and Methylarcula terricola [22] and in the deep sea organism Photobacterium profundum SS9 [52]. The role of polyhydroxybutyrates in the deep sea bacterium is particularly intriguing. In $P$. profundum, betaine and glutamate represent the major solutes when the cells are grown at $1 \mathrm{~atm}$. However, when grown at $280 \mathrm{~atm}, \beta$-hydroxybutyrate and polymers of this solute accumulate and become the major solutes. At a fixed hydrostatic pressure, $\beta$ hydroxybutyrates also increase with increasing external
$\mathrm{NaCl}$ (particular at high pressures), indicating that the monomer and possibly the polymer (although the enhanced intensity in the NMR resonances for this compound could also indicate increased chain length) function as conventional osmolytes. Because their intracellular levels respond to hydrostatic as well as osmotic pressure, these $\beta$-hydroxybutyrate solutes in this organism have been termed 'piezolytes' [52].

\section{Anionic polyols and carbohydrates}

In bacteria, high intracellular concentrations of negatively charged carbohydrates are not very common. Two such solutes that have been detected include $\alpha$-glucosylglycerate and $\alpha$-mannosylglycerate. These solutes tie up the reactive end of the sugar in a glycosidic bond with a hydroxyl group of glyceric acid. $\alpha$-Mannosylglycerate, accumulated by several Rhodothermus spp., is higher in exponential phase cells and decreases abruptly as cells enter stationary phase [34]. These cells accumulate both the anion mannosylglycerate and the neutral $\alpha$-mannosylglyceramide. Which of these two solutes dominates depends on stress conditions. Under temperature stress of the cells, $R$. marinus is biased towards accumulating mannosylglycerate; increased $\mathrm{NaCl}$ favored accumulation of the neutral $\alpha$-mannosylglyceramide rather than the organic anion [34]. Glucosylglycerate has also been observed in Methanohalophilus portucalensis when those cells are grown with methanol rather than methylamine as the substrate for methanogenesis [30]. It is a relatively minor contributor to osmotic balance under those conditions, but the cells do synthesize it. Its turnover, measured by NMR, is roughly twice as slow as $\alpha$-glutamate and $2-4$ times faster than turnover of the zwitterions betaine and $N \varepsilon$-acetyl- $\beta$-lysine [30].

Halotolerant archaea (excluding most methanogens) tend to accumulate organic anions where the negative charge is often provided by a phosphate moiety and in some cases by sulfate added to a noncharged solute (Figure 4). Representatives of this class of compounds include the glycerol derivative $\alpha$-diglycerol phosphate [53] and a series of $m y o$ inositol phosphodiesters based on di-myo-inositol-1,1'phosphate (DIP) $[9,10]$. Phosphodiesters are better choices than phosphomonoesters for accumulation at high concentrations since they will have weaker interactions with cations (particularly divalent cations). DIP and its relatives (e.g., mannosyl-DIP [54]) are associated with halotolerant hyperthermophiles. The intracellular concentration of these solutes increases with external $\mathrm{NaCl}$, but the increase is usually more striking with growth temperatures above $80^{\circ} \mathrm{C}[10,55-57]$. In Archaeoglobus fulgidus grown at $76^{\circ} \mathrm{C}, \alpha$-diglycerol phosphate is the major osmolyte, varying with external $\mathrm{NaCl}$; little if any DIP is detected. However, at $87^{\circ} \mathrm{C}$ DIP concentrations are comparable to the $\alpha$-diglycerol phosphate [58]. The 
association of DIP with very high temperatures suggests that this and related solutes have a role in stabilizing macromolecules to high temperature, although why this odd sugar is used is not clear. Synthesis of DIP from glucose-6phosphate requires significant energy, so that there must be a reason for its accumulation.

A few archaea have been seen to accumulate cyclic-2,3diphosphoglycerate, an unusual cyclic pyrophosphate with a net -3 charge. This solute was first detected in strains of Methanothermobacter thermoautotrophicus $[59,60]$, a thermophilic methanogen that is usually grown in medium containing low $\mathrm{NaCl}$. In the Marburg strain of that organism 1,3,4,6-tetracarboxyhexane, a component of methanofuran, is also a major solute [61]. Cyclic-2,3diphosphoglycerate is also accumulated in Methanobrevibacter smithii, Methanopyrus kandleri and Methanothermus fervidus [58,62]. However, at least in M. thermoautotrophicus it has unusual behavior compared to most osmolytes. It exhibits very rapid turnover in the cells (compared to the cell doubling time) and appears to be fixed into a polymer pool from which it can be retrieved in times of stress $[63,64]$. Furthermore, its intracellular concentration does not vary much, even when the cells are grown in $0.4 \mathrm{NaCl}$ [61]. This behavior could suggest it has a primary role as a carbon and phosphate storage compound in these methanogens.

Another unusual anionic solute found in haloalkaliphilic archaea is sulfotrehalose [65]. This derivative of trehalose with a sulfate at $\mathrm{C} 2$ of one of the glucose rings was the major solute in several Natronococcus and Natronobacterium species grown in defined media. The intracellular sulfotrehalose increases with increased external $\mathrm{NaCl}$ and is accumulated in amounts comparable to the intracellular $\mathrm{K}^{+}$(P. Jablonski, unpublished results). However, the sulfotrehalose can be replaced by sucrose, in which case the cells have roughly double the amount of organic solute. Interestingly, sulfatides with sulfotrehalose (modified tehalose 2'-sulfate with acyl chains on the other glucose moiety attached to $\mathrm{C} 2$ and $\mathrm{C} 3$ ) are synthesized in $\mathrm{Myco-}$ bacterium tuberculosis [66]. Whether or not such sulfatides exist in the archaea has not been determined.

\section{D. $K^{+}$and other inorganic ions}

The high concentration of organic anions in many halophiles requires counterions such as $\mathrm{K}^{+}$and/or $\mathrm{Na}^{+}$. However, there are halophiles that exclusively use inorganic ions for osmotic balance. Halophilic aerobic archaea have been shown to have high $\mathrm{K}^{+}$and $\mathrm{Cl}^{-}[67]$, although absolute amounts appear to depend dramatically on the method of analysis and/or growth conditions. There are also bacteria with exceedingly high intracellular $\mathrm{K}^{+}$. In Salinibacter ruber, an obligatory aerobic chemoorganitrophic and very halophilic bacterium, $\mathrm{K}^{+}$is the major intracellular component of osmotic balance with 11-15 $\mu \mathrm{mol} \mathrm{K}^{+} / \mathrm{mg}$ protein [68]. Organic solutes are relatively low in this organism; these studies used elemental analysis with EM and an X-ray spectrum to describe constituents and flame-photometric determination of $\mathrm{K}^{+}$. S. ruber occupies a relatively unique position in the bacterial kingdom. Its closest relative, Rhodothermus marinus, uses $\alpha$ mannosylglycerate and $\alpha$-mannosylglyceramide as osmolytes for osmotic balance [34].

Other microorganisms that do not appear to use organic osmolytes for balance include anaerobic fementative members of the families Halobacteroidaceae and Halanaerobiaceae [67-70]. Halobacterium salinarum, an archaeon, has been reported to accumulate $12 \mu \mathrm{mol} \mathrm{K+}$ mg protein. While some organic solutes were observed ( $\leq 50 \mathrm{mM}$ ), at those low concentrations they are unlikely to play a major role in osmotic balance, although they may aid in charge balance within the cells. Using a cell volume of $2.75 \mu \mathrm{l} / \mathrm{mg}$ proteins for $H$. salinarum, the estimated intracellular $\mathrm{K}^{+}$is $4.4-4.8 \mathrm{M}$ comparable to the $\mathrm{Na}^{+}$ concentration in the medium. Extracting cell pellets prior to $\mathrm{K}^{+}$analyses led to considerably lower values ( $\sim \mathrm{M}$ for $S$. ruber and $\sim 3 \mathrm{M}$ for $H$. salinarum) for $\mathrm{K}^{+}$, suggesting ion leakage. Intracellular $\mathrm{Na}^{+}$was also high in the pellet extracts, which could suggest problems with this type of analysis. Alternatively, the difference might reflect complexed versus uncomplexed ions. Halophilic sulfatereducing bacteria, e.g., Desulfohalobium retbaense and Desulfovibrio halophilus, like the haloarchea, appear to use inorganic salts for osmotic balance.

In contrast to the archaeal halophiles, many of the halophilic bacteria do not have exceptional high $\mathrm{K}^{+}$. For example, Halomonas elongata accumulates $1.1 \mu \mathrm{mol} \mathrm{K}^{+} / \mathrm{mg}$ protein when grow with yeast extract and $2.2 \mu \mathrm{mol} / \mathrm{mg}$ protein when grown in defined medium with glucose as the sole carbon source. In Halanaerobium acetethylicum grown in medium with $1.7 \mathrm{M} \mathrm{NaCl}$, the internal cytoplasmic $\mathrm{Na}^{+}$and $\mathrm{Cl}^{-}$are 0.92 and $1.2 \mathrm{M}$, respectively, while $\mathrm{K}^{+}$ and $\mathrm{Mg}^{2+}$ concentrations in cells are 0.24 and $0.02 \mathrm{M}$, respectively [70].

Although $\mathrm{K}^{+}$(and occasionally $\mathrm{Na}^{+}$) appears to be the major intracellular cation, there are reports that, in some cells, $\mathrm{Mg}^{2+}$ can reach moderately high concentrations. Heldal and coworkers [71] have found high $\mathrm{Mg}^{2+}$ (close to $0.9 \mathrm{M}$ ) in native marine bacteria under conditions of low dissolved organic carbon. The intracellular $\mathrm{Mg}^{2+}$ was dramatically reduced $(<0.2 \mathrm{M})$ when nutrient levels increased. They suggested that high intracellular $\mathrm{Mg}^{2+}$ is a marker of carbon limitation.

Chloride is the most prevalent inorganic anion in halophiles that do not accumulate organic anions. Molar 
concentrations of chloride have been detected in several halophilic archaea. This anion is pumped into cells by halorhodopsin or cotransported with $\mathrm{Na}^{+}$. While this anion certainly can contribute to osmotic balance, it appears to have more critical roles in haloadaptation [72]. For example, chloride has been shown to regulate betaine transport. Aside from chloride, little is known about the inorganic anion composition of halophiles. However, a recent FT-IR study of intact bacteria during growth indicates that in H. salinarum and Halococcus morrhuae, large changes occur in the concentration of sulfate ion in the cells [73]. Maximum sulfate occurs during the mid-part of the exponential phase.

\section{E. Cocktails of organic solutes}

One of the things arising from the studies of different halotolerant and halophilic organisms is that most cells use an array of solutes, not a single one, for osmotic balance. When a single solute is detected it is often supplied by the medium and efficiently transported into the cell. However, left to its own device, the typical bacterial or archaeal cell synthesizes several molecules that together contribute to osmotic balance. Sometimes this is a combination of anions and zwitterions, but often several solutes with the same net charge. Archaea provide particularly intriguing examples of this strategy, although an explanation for the diversity of solutes in a given organism is lacking.

Methanothermococcus thermolithotrophicus accumulates the anionic $\alpha$ - and $\beta$-glutamate when grown in medium with less than $1 \mathrm{M} \mathrm{NaCl}$ [49]. Cells adapted to higher external $\mathrm{NaCl}$ concentrations switch to accumulating a zwitterions, $N \varepsilon$-acetyl- $\beta$-lysine $[31,48,50]$. Since the glutamate concentration is roughly the same as intracellular $\mathrm{K}^{+}$, the switch to accumulating the zwitterions could be the result of an impaired $\mathrm{K}^{+}$pump.

Methanohalophilus portucalensis, a halophilic methanogen, accumulates three zwitterions over its growth range: betaine, $N \varepsilon$-acetyl- $\beta$-lysine, and $\beta$-glutamine [8]. $\alpha$-Glutamate is detected, but its intracellular concentration is relatively low and does not increase with increased external $\mathrm{NaCl}$. Of the three zwitterions, $\beta$-glutamine is only accumulated to large amounts at the high $\mathrm{NaCl}$ end of the growth range. Several conditions can affect the balance among these three zwitterions [30]. The cells can grow on trimethylamine or methanol as the substrate for methanogensis, and the substrate with nitrogen promoted accumulation of the two solutes containing two nitrogen atoms (Ne-acetyl- $\beta$-lysine, and $\beta$-glutamine). Supplying precursors of these solutes (glycine, lysine, glutamate) has little effect on the distribution of the three zwitterions. Betaine is the only solute that could suppress synthesis of both $N \varepsilon$-acetyl- $\beta$-lysine and $\beta$-glutamine when it is present in the medium [74].

Balancing several different anionic osmolytes has also been observed in the halotolerant, hyperthermophilic Methanotorris igneus, which accumulates L- $\alpha$-glutamate, $\beta$ glutamate, and DIP [10]. Increased external $\mathrm{NaCl}$ leads to preferential increases in the intracellular $\beta$-amino acid; thermal stress causes increases in DIP levels. Multiple anionic solutes are also accumulated in other hyperthermophilic archaea. In Archaeoglobus fulgidus, glutamate, DIP and $\alpha$-diglycerol phosphate are used for osmotic balance [53]. In these cells, it is the $\alpha$-diglycerol phosphate that was most sensitive to external $\mathrm{NaCl}$ while heat enhanced DIP synthesis and accumulation.

\section{Biosynthesis of Osmolytes - Novel Pathways and Regulation \\ A. Betaine}

Microorganisms have two different general pathways for synthesizing betaine (Figure 5). The oxidative pathway can occur with a single soluble enzyme (choline oxidase in Gram-positive soil bacteria [75]) or require two distinct soluble enzymes (choline monooxygenase and betainealdehyde dehydrogenase in higher plants [76]), or it can occur with a membrane-associated system coded by four genes in the bet operon (in marine invertebrates and bacteria including Escherichia coli). The last system has been studied genetically [77], with genes identified for choline dehydrogenase (betA), betaine-aldehyde dehydrogenase $($ bet $B)$, a choline transporter (bet $T)$ and a putative regulator (betI). The choline dehydrogenase catalyzes oxidation of choline to betaine aldehyde, which is then oxidized to betaine by the bet $B$ gene product. In Pseudomonas, an electron acceptor other than $\mathrm{O}_{2}$ is used for choline oxidation with suggestions that PQQ is the acceptor [78]. In Actinopolyspora halophila, choline is oxidized to betaine aldehyde then to betaine [36]. The aldehyde is produced with $\mathrm{O}_{2}$ consumption and $\mathrm{H}_{2} \mathrm{O}_{2}$ generation. The final oxidation to betaine uses reduction of NADP+.

Even organisms that do not accumulate betaine in response to osmotic stress may have homologues of the genes for synthesizing this solute. Halomonas elongata does not appear to accumulate betaine. However, the organism does have a gene that codes for the oxidation of choline to betaine [79]. Recently the choline dehydrogenase from that organism was expressed in E. coli and characterized. This enzyme can use $\mathrm{O}_{2}$ if no other electron acceptors are available, although $\mathrm{V}_{\max }$ decreases four-fold compared to kinetics with an acceptor such as phenazine methosulfate. Both choline and the betaine-aldehyde are converted to betaine. Although a glycine box suggestive of $\mathrm{FAD}^{+}$as a cofactor was seen in the sequence, there is no experimental evidence for $\mathrm{FAD}^{+}$as a cofactor. These observations 


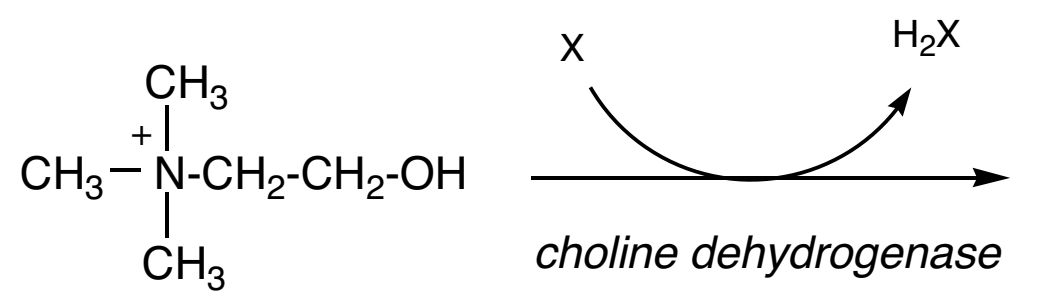<smiles>C[N+](C)(C)CC=O</smiles><smiles>[Y]CC1CCCCCC1</smiles><smiles>C[N+](C)(C)CC(=O)[O-]</smiles>

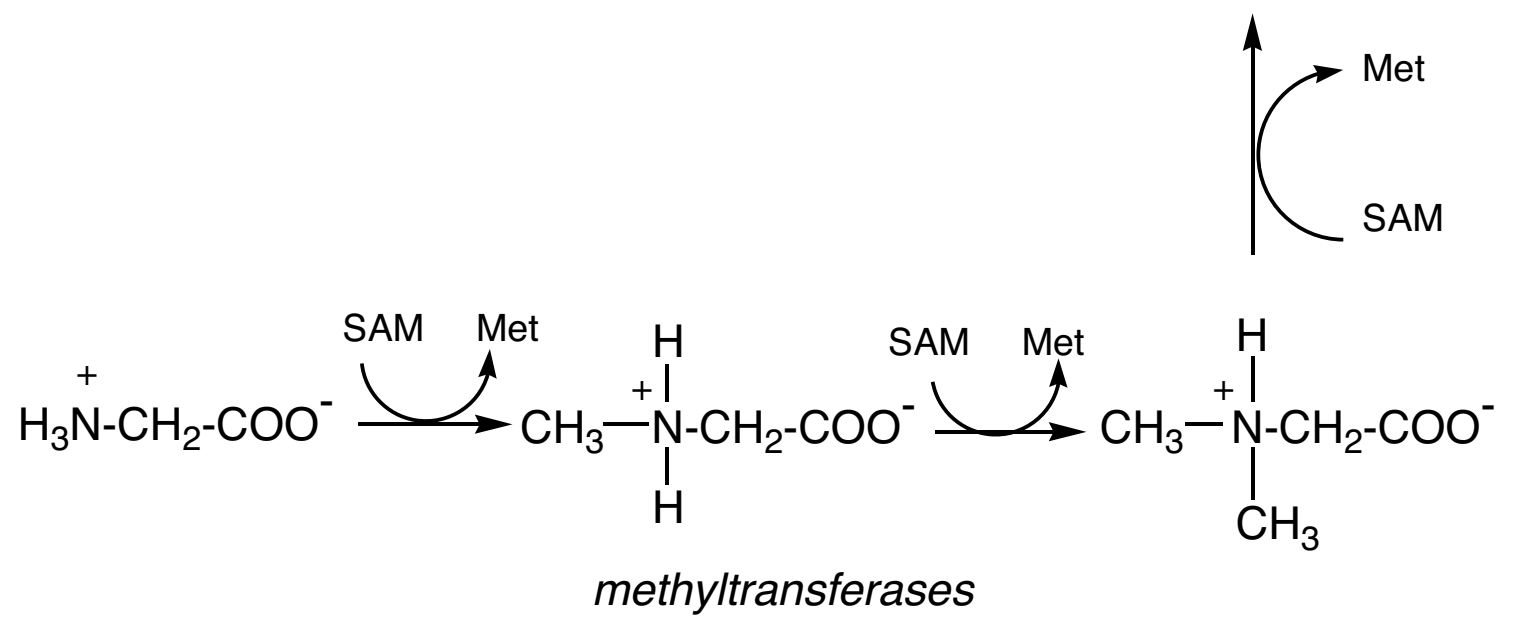

Figure 5

Pathways for synthesizing betaine in bacteria and archaea.

prompt two questions: (1) what cofactor is used by this choline dehydrogenase, and (ii) under what conditions is this gene expressed?

Several microorganisms can also generate betaine by successively methylating glycine. GSMT (glycine sarcosine methyltransferase) and SDMT (sarcosine dimethylglycine methyltransferase) in Halorhodospira halochloris and Actinopolyspora halophila transfer the methyl group of S-adenosylmethionine to two different types of amines $[18,36,80]$. Betaine synthesis from glycine in a halotolerant photosynthetic organism Aphanothece halophytica was 
also carried out by GSMT and DNMT activities [81]. Only one methanogen, Methanohalophilus portucalensis, has been shown to synthesize betaine de novo [8]. In these anaerobic cells, ${ }^{13} \mathrm{C}$ NMR labeling experiments suggest that betaine is generated by successive methylation of glycine [20]. If cells are grown with $10 \mathrm{mM}$ betaine in the medium, accumulation of other osmolytes ( $\mathrm{N} \varepsilon$-acetyl- $\beta$ lysine, $\beta$-glutamine and glucosylglycerate) is suppressed [74]. However, supplying cells with betaine precursors does not necessarily alter the distribution of osmolytes. Exogenous glycine or sarcosine had no effect on betaine accumulation. Even though the glycine $\left({ }^{13} \mathrm{C}\right.$-labeled $)$ was shown to be internalized by the cells [74], betaine synthesis and suppression of other osmolytes only occurs with $\mathrm{N}, \mathrm{N}$-dimethylglycine added. This suggests that it is the $\mathrm{N}, \mathrm{N}$-dimethylglycine intracellular concentration that regulates betaine synthesis and accumulation. Recently a $240 \mathrm{kDa}$ N-methyl transferase has been isolated and partially characterized (M.-C. Lai, C.-C. Wang, M.-J. Chuang, Y.-C. $\mathrm{Wu}$, and Y.-C. Lee, personal communication). The source of the methyl groups transferred to glycine is (perhaps not surprisingly) S-adenosylmethionine. While mammalian activites usually show very specific methyltransferase activity (e.g., glycine N-methyltransferase), an aggregate of similar mass proteins (but with different pI values) carries out all three methylation activities in the methanogen. Different subunits in the aggregate are optimized for different methyl transfers; the $\mathrm{K}^{+}$concentration also differentially modulates the methyltransferase activities [[82], M.-C. Lai and coworkers, personal communication]. The last result suggests that betaine accumulation is likely regulated by the internal $\mathrm{K}^{+}$concentration in these cells.

\section{B. Ectoine}

The biosynthesis and regulation of ectoine in cells have been studied in several different bacteria, both Gram-negative and Gram-positive. Biosynthesis of ectoine in $H$. elongata has been studied in the greatest detail. The entry molecule into ectoine biosynthesis is aspartate semialdehyde, which is an intermediate in amino acid metabolism [83]. A shown in Figure 6, the aldehyde is converted to L2,4-diaminobutyric acid, which is then acetylated to from $\mathrm{N} \gamma$-acetyldiaminobutyric acid (NADA). The final step is the cyclization of this solute to form ectoine. The genes for biosynthesis of this solute were identified after the isolation of salt-sensitive mutants led to cloning of genes [84]. Ectoine synthesis is carried out by the products of three genes: ectABC. The ectA gene codes for diaminobutyric acid acetyltransferase; ectB codes for the diaminobutyric acid aminotransferase; ect $C$ codes for ectoine synthase $[19,85]$. The three recombinant $H$. elongata Ect enzymes have been characterized. The first enzyme (a $260 \mathrm{kDa}$ complex of $44 \mathrm{kDa}$ subunits) generates the diaminobutyrate by transaminating the aspartate semialdehyde with glutamate. Both pyridoxal 5'-phosphate and $\mathrm{K}^{+}$are necessary for the diaminobutyrate aminotransferase activity [86]. The aminotransferase of step two is activated by 0.5 $\mathrm{M} \mathrm{NaCl}$ (and similarly by $\mathrm{KCl}$ ). The last enzyme involved, ectoine synthase, is also activated by $\mathrm{NaCl}$. This suggests that ectoine accumulation is partially regulated by intracellular cations.

In Chromohalobacter salexigens, the ectABC genes are regulated at the transcriptional level [87]. Osmoregulated promoters with sequence homology to general stress $\sigma$ factor have been identified. Since ectoine levels are modulated with betaine present, there must be additional post-transcriptional control. The effect of betaine on ectABC expression and ectoine accumulation was also shown in Marinococcus halophilus [88]. In defined medium, the intracellular level of ectoine increases with $\mathrm{NaCl}$ and suppresses accumulation of trehalose. However, in complex medium, betaine is accumulated and ectoine synthesis is suppressed.

In most organisms, it is thought that hydroxyectoine is synthesized directly from ectoine. However, $H$. elongata has an alternate pathway that was observed in strains defective in EctC. These mutants that can not synthesize ectoine can still convert NADA directly to hydroxyectoine [89]. Canovas et al. [89] proposed that NADA is hydroxylated to 3-hydroxyl-N $\gamma$-acetyldiaminobutyrate, which is then cyclized to hydroxyectoine by 'hydroxyectoine synthase.' The zwitterionic precursor of ectoine can also be accumulated for osmotic balance. NADA has been detected in a salt-sensitive strain of $H$. elongata [89] that grows optimally with 0.75 to $1.0 \mathrm{M} \mathrm{NaCl}$. It accounts for $80 \%$ of the organic solute pool for cells grown in $1.5 \mathrm{M}$ $\mathrm{NaCl}$ ) with ectoine $(6 \%)$ and hydroxyectoine $(12 \%)$ also present. NADA confers higher osmotic stability to the cells than in a H. elongata mutant where diaminobutyrate accumulates [84]. Thus, this solute, but not its diaminobutyrate precursor (which would have a net positive charge) can act as a compatible solute if ectoine synthesis is blocked.

\section{C. $\beta$-amino acids}

Over the past few years, genes have been identified or proteins isolated or cloned that confirm pathways initially proposed based on ${ }^{13} \mathrm{C}$ isotopic labeling of these solutes. The pathway originally proposed for biosynthesis of $\mathrm{N \varepsilon}$ acteyl- $\beta$-lysine has two key enzymes: (i) isomerization of $\alpha$-lysine to $\beta$-lysine catalyzed by a lysine aminomutase, then (ii) acetylation of the $\varepsilon$-amino group [20,31]. Recently the genes coding for these two enzymes were identified in Methanosarcina mazei Gö1 [90]: ablA codes for the aminomutase while ablB codes for the $\beta$-lysine acetyltransferase. Expression of the two genes, which are organized in an operon, is salt dependent in M. mazei. 

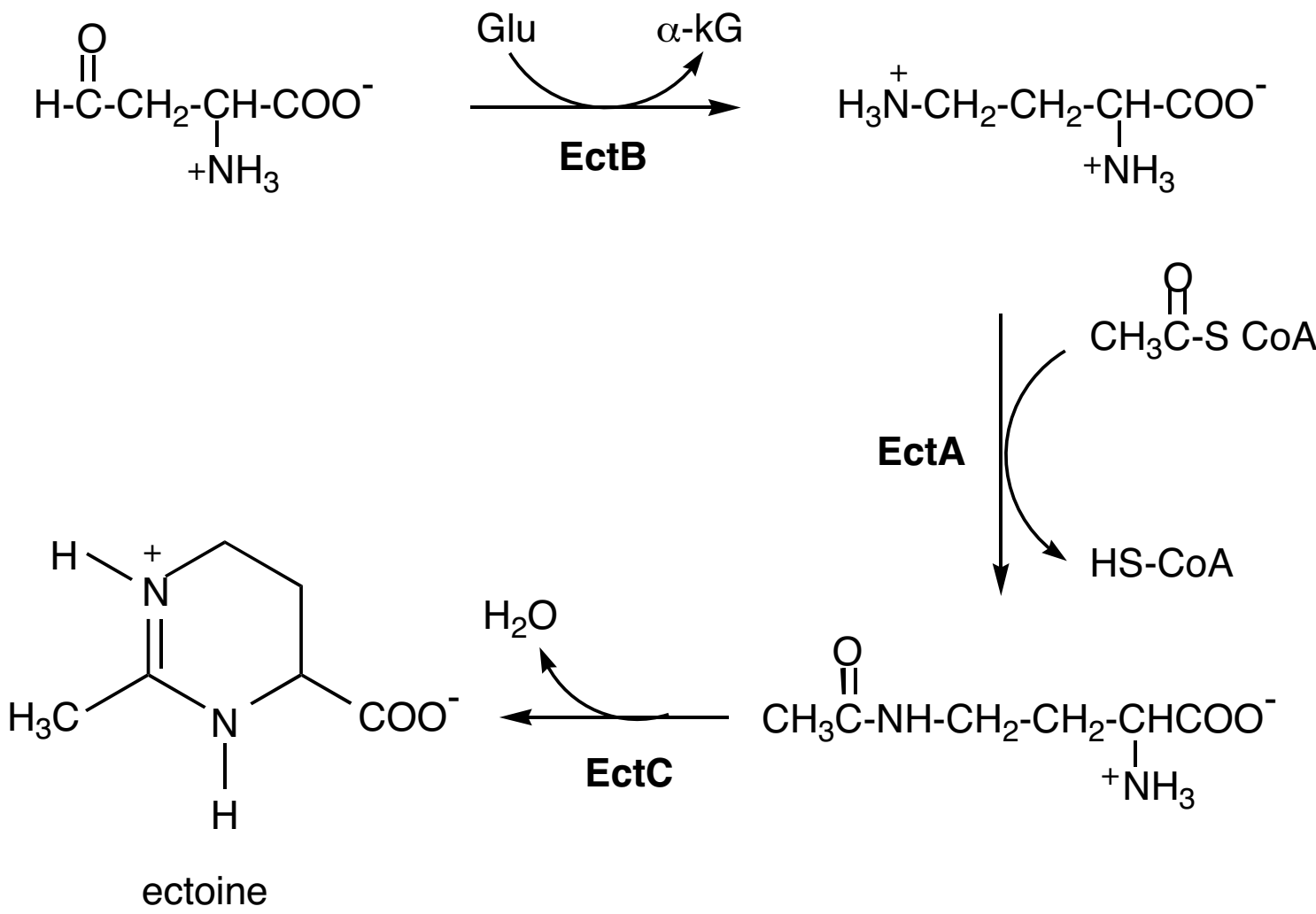

Figure 6

Biosynthetic pathway for ectoine.

Several other methanogens, including Methanococcus maripaludis, have homologous genes [90]. Deletion of the $a b l$ operon in M. maripaludis generates cells incapable of growth in high salt medium. It will be interesting to characterize the methanogen lysine aminomutase and to compare it to the catabolic enzyme from bacteria that carries out the same chemistry.

Early NMR evidence ruled out a glutamate aminomutase activity as a means of generating $\beta$-glutamate [31] but did not identify precursors. As shown in Figure 7 , the most likely pathway (proposed based on enzyme activities found in Methanocaldococcus jannaschii by M. Graupner, H. Xu, and R. H. White, personal communication) starts with the reduction of $\alpha$-ketoglutarate to $\alpha$-hydroxyglutarate, which is converted to its coenzyme A ester. Elimination of water from the $\alpha$-hydroxyglutaryl-CoA generates
glutaconyl-CoA, which forms $\beta$-glutamyl-CoA when ammonia is added (although the direct source of ammonia is not clear). Hydrolysis of the CoA ester generates $\beta$ glutamate. The products of the MJ0800 and MJ0400 genes have been identified as the enzymes responsible for water elimination in this pathway by R. H. White and coworkers (personal communication).

While not all the enzymes for synthesizing $\beta$-glutamate have been identified, conversion of $\beta$-glutamate to $\beta$ glutamine is done in Methanohalophilus portucalensis FDF1 by glutamine synthetase $[20,91]$. That GS has unusual properties compared to other studied GS enzymes. In particular, its activity with $\beta$-glutamate as substrate is much higher than that of other organisms [91]. Regulation of the enzyme must occur in the cell, because $\beta$-glutamine is only accumulated to NMR-detectable levels in $M$. 


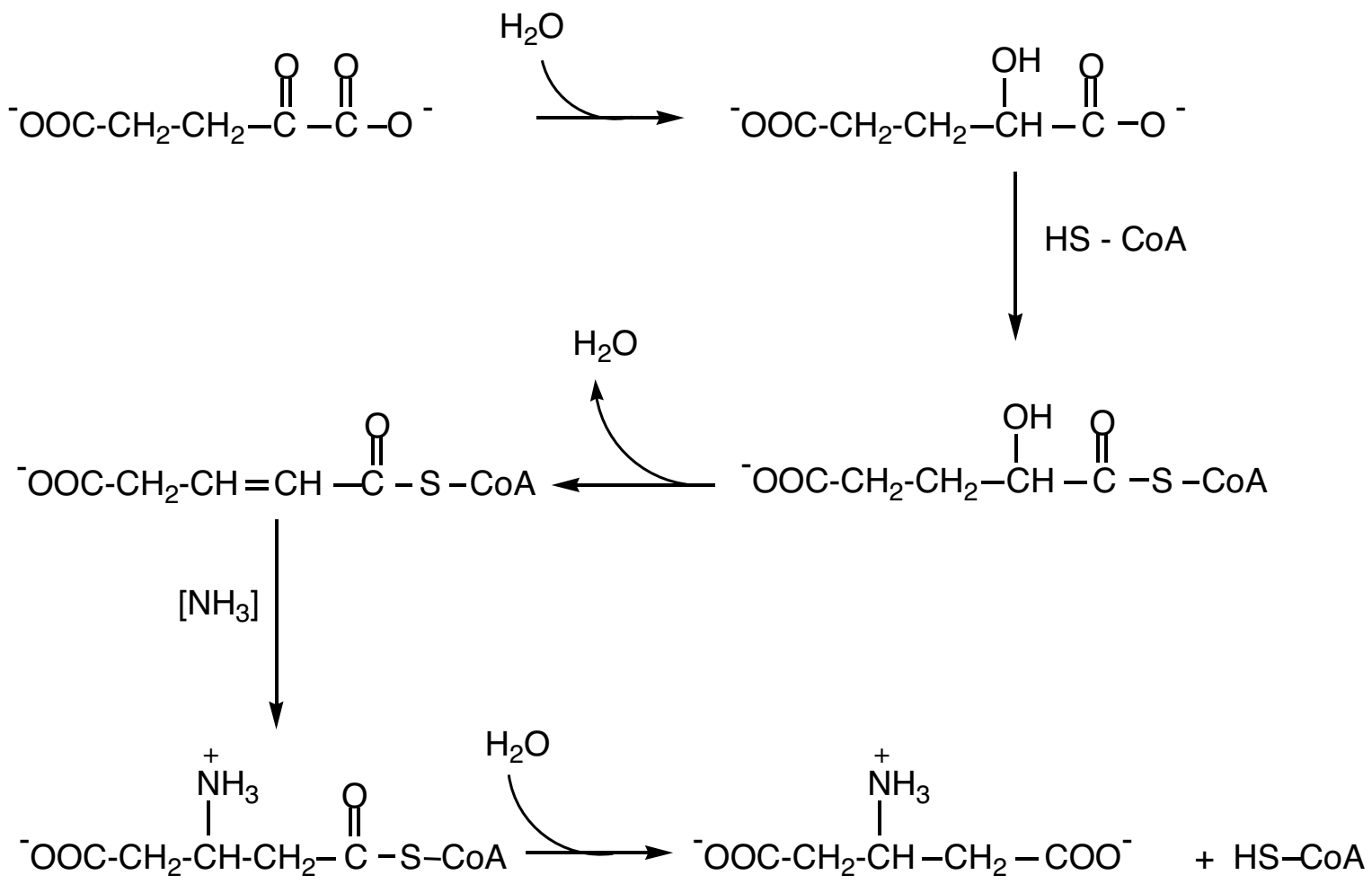

Figure 7

Proposed biosynthetic pathway for $\beta$-glutamate.

portucalensis when the cells are grown at higher $\mathrm{NaCl}[8]$. Although the in vitro $\mathrm{K}_{\mathrm{m}}$ values for both $\alpha$ - and $\beta$-glutamate in this organism appear quite high, there is likely to be another mechanism responsible for regulation of the synthesis of this solute by glutamine synthetase and accumulation for osmotic balance.

\section{DIP}

Data from NMR experiments using ${ }^{13} \mathrm{C}$-labeled precursors to label DIP in Methanotorris igneus coupled with in vitro assays with postulated intermediates [92] led to a pathway for the biosynthesis of DIP that includes four steps (Figure 8): (i) conversion of D-glucose-6-phosphate to L-inositol1-phosphate (L-I-1-P) via inositol-1-phosphate synthase (IPS); (ii) hydrolysis of the L-I-1-P by inositol monophoshatase; (iii) coupling of the L-I-1-P with CTP to form CDP-inositol; and (iv) generation of the phosphodiester linkage by condensing CDP-inositol with L-I-1-P (via a
'DIP synthase' activity for whom there is yet no candidate in genomes of organisms that accumulate DIP). In P. woesei, but not in M. igneus, DIP could also be generated from incubations of crude cell extracts with GTP and I-1-P [93]. This finding can be explained by the same condensation mechanism, but assuming a multifunctional 'DIP synthase' that catalyzes not only the condensation of CDP-I and myo-inositol but the dephosphorylation of I-1-P as well (presumably without releasing the dephosphorylated product, myo-inositol).

The IPS reaction has been examined in several hyperthermophiles (Archaeoglobus fulgidus, Methanotorris igneus, Pyrococcus furiosus, P. woesei, and Thermotoga maritima) known to accumulate this solute (L. Chen and M.F. Roberts, unpublished results). IPS activities in crude extracts are ubiquitous in these organisms and fall into two classes: (i) IPS dependent on divalent cations $\left(\mathrm{Mn}^{2+}\right.$ or 

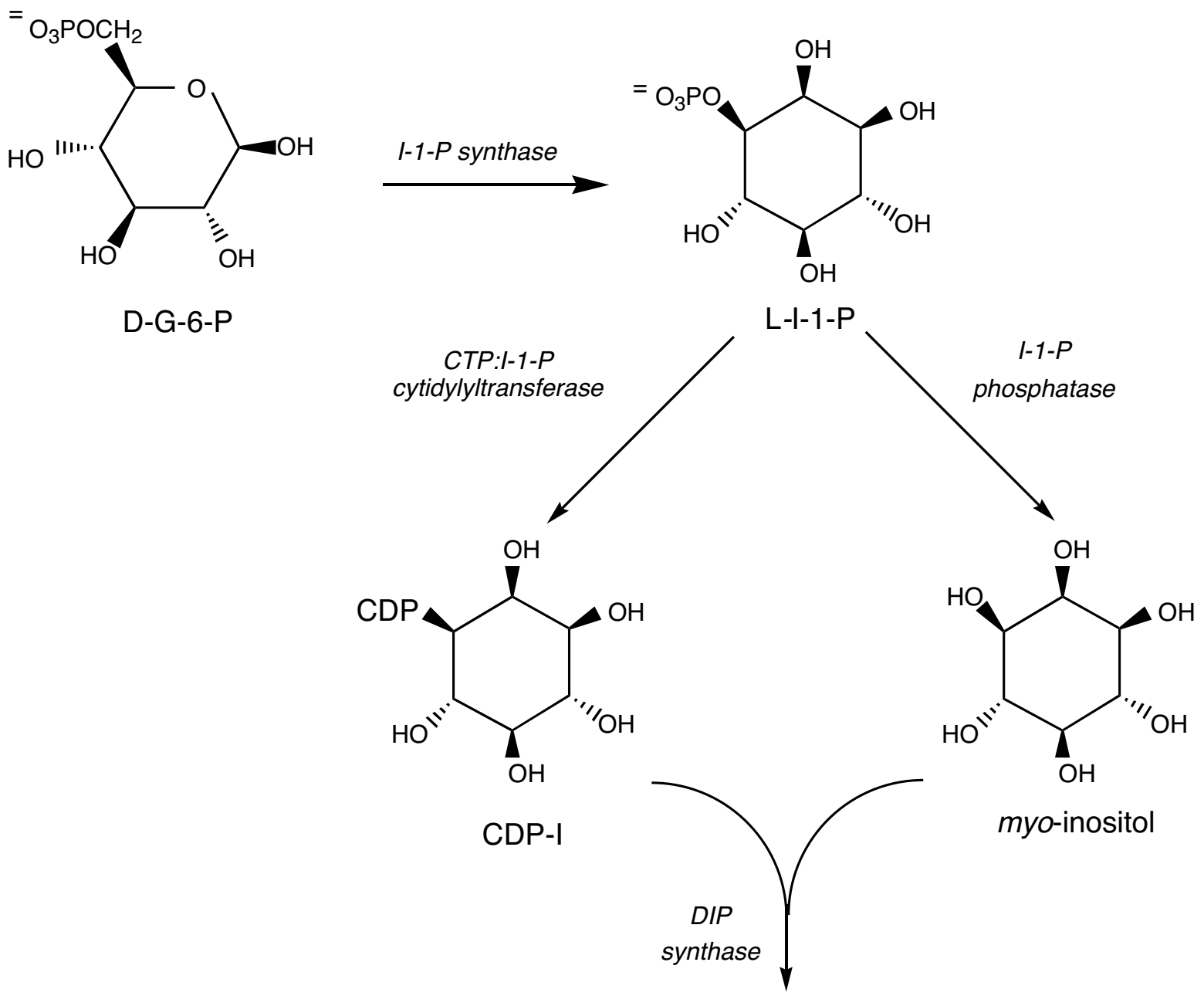

D-G-6-P

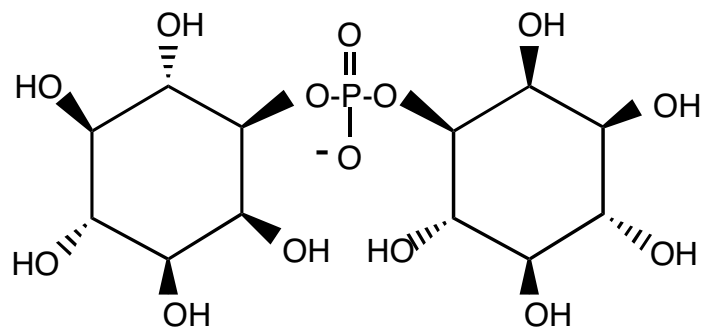

L,L- DIP

Figure 8

Proposed pathway for DIP biosynthesis in hyperthermophilic organisms.

$\mathrm{Zn}^{2+}$ ) is detected in A. fulgidus, while (ii) the IPS activities from the other organisms are not activated by metal ions or $\mathrm{NH}_{4}+$ (the cofactor for all other known IPS). Although it is the first step in DIP synthesis, the IPS reaction is unlikely to be the point where DIP synthesis and accumulation are regulated since many archaea incorporate inosi- 
tol into their lipids. If they incorporate L-I-1-P into lipids, then the second step, the generation of myo-inositol could be a way to regulate flow of resources into DIP.

The archaeal IMPase enzymes, easily identified by sequence homology to mammalian IMPases, have unusual properties. They exhibit similar substrate specificity to eukaryotic IMPases with one curious exception - they very specifically can dephosphorylate the phosphate on C1 of fructose bisphosphate [94]. The FBPase activity identifies this class of enzymes as dual phosphatases that can process substrates in completely different pathways. FBPase activity gives it a potential role in gluconeogenesis. However, a 'true' FBPase with a homologue in all archaeal genomes was recently purified and cloned $[95,96]$, so that the IMPase/FBPase in archaea may normally function as an IMPase, (although, Methanocaldococcus jannaschii does not accumulate DIP, has no IPS sequence homologue, yet still has a gene for an IMPase/FBPase homologue which has been expressed and characterized [97]). Nonetheless, it is intriguing that an enzyme that could act as either an IMPase or FBPase under the right circumstances (salt or temperature stress?) could link carbohydrate synthesis with responses to stress. At least for the IMPase from $A$. fulgidus, there are hints as to what could regulate this enzyme. This IMPase has two spatially close cysteine residues that can be oxidized to form a disulfide (either by vigorus bubbling with $\mathrm{O}_{2}$ at $85^{\circ} \mathrm{C}$ or by adding oxidized E. coli thioredoxin [98]). Formation of the intramolecular disulfide inactivates the enzyme; treatment with either a reducing agent or a reduced thioredoxin can regenerate active enzyme. Unfortunately, the lack of genetics with $A$. fulgidus makes it difficult to see what role this protein does play in hyperthermophiles. Although enzymes for the third and fourth steps in DIP production have not been identified, the last step has been demonstrated with cell extracts and added CDP-inositol and myo-inositol (L. Chen and M.F. Roberts, unpublished results). DIP synthesis required the presence of $\mathrm{Mg}^{2+}$.

\section{E. $\alpha$-Mannosylglycerate ( $\alpha \mathbf{M G )}$}

The synthesis of this osmolyte has been examined in several hyperthermophiles. There appear to be two distinct pathways (Figure 9). In R. marinus, there is a direct condensation of GDP-mannose and D-glycerate to form $\alpha$ MG catalyzed by mannosylglycerate synthase [99]. A second pathway, used by hyperthermophilic archaea, converts GDP-mannose and D-3-phosphoglycerate to mannosyl-3-phosphoglycerate via mannosyl-3-phosphoglycerate synthase, followed by phosphoglycerate phosphatase activity to remove the phosphate group $[100,101]$.

\section{F. Cyclic-2,3-diphosphoglycerate (cDPG)}

The biosynthesis of the solute CDPG diverts resources from gluconeogenesis by phosphorylation of 2-phosphoglycerate (2-PG) with ATP to form 2,3-diphosphoglycerate (DPG) via 2-phosphoglycerate kinase [102]. Different transformations involving cDPG production and hydrolysis are shown in Figure 10. A novel enzyme, cyclic 2,3-diphosphoglycerate synthetase (cDPGS) $[103,104]$ then converts DPG to the cyclic form with ATP hydrolysis driving the reaction. Hydrolysis of cDPG to 3PG would shuttle carbon and phosphate back into gluconeogenesis. In Methanothermus fervidus cDPGS is reversible, although it prefers the direction of cDPG synthesis [104]. The ability to generate ATP from ADP, inorganic phosphate Pi) and cDPG under these conditions could argue for a role in energy storage in that organism. However, in Methanobacter thermoautotrophicus, the $\mathrm{K}^{+}$-activated cDGPS appears irreversible (and membranebound), suggesting it may have a different role [105]. In soluble cell extracts, hydrolysis of CDPG in the presence of ADP and Pi could not generate ATP [106]. However, a membrane bound hydrolase that is inhibited by $\mathrm{K}^{+}$and $\mathrm{Pi}$ has also been identified [105]. The regulation of cDPG degradation in M. thermautotrophicus is consistent with it playing a role as a carbon and phosphate storage compound, although its high concentration in cells clearly indicates it contributes to osmotic balance.

\section{Transport of Osmolytes}

Osmolyte transporters also play important roles in the osmotic response. Some of these transporters are very specific and serve to retrieve any solute released by cells. Others have evolved to scavenge solute or osmolyte precursors so that the more wasteful biosynthetic resources of the cell are not used. Recent years have witnessed progress in identifying and characterizing the proteins responsible for uptake of the osmolytes betaine and ectoine from the medium. In other cases putative transporter genes have been identified but no accumulation of the solute is observed. A summary of the different types of betaine (and one ectoine) transporters is presented in Table 1. Another category of membrane proteins involved in osmolyte movement are the mechanosensitive channels. These are the major players in responding to hypoosmotic stress in that they serve as the conduits for solute removal from the cytoplasm. A recent review on many of the membrane proteins acting as osmosensors can be found in [107].

\section{A. Betaine}

Betaine transport is common to a wide variety of halotolerant and halophilic organisms, both bacteria and archaea. There are basically two superfamilies of betaine transporters: (i) secondary transporters that use either the 


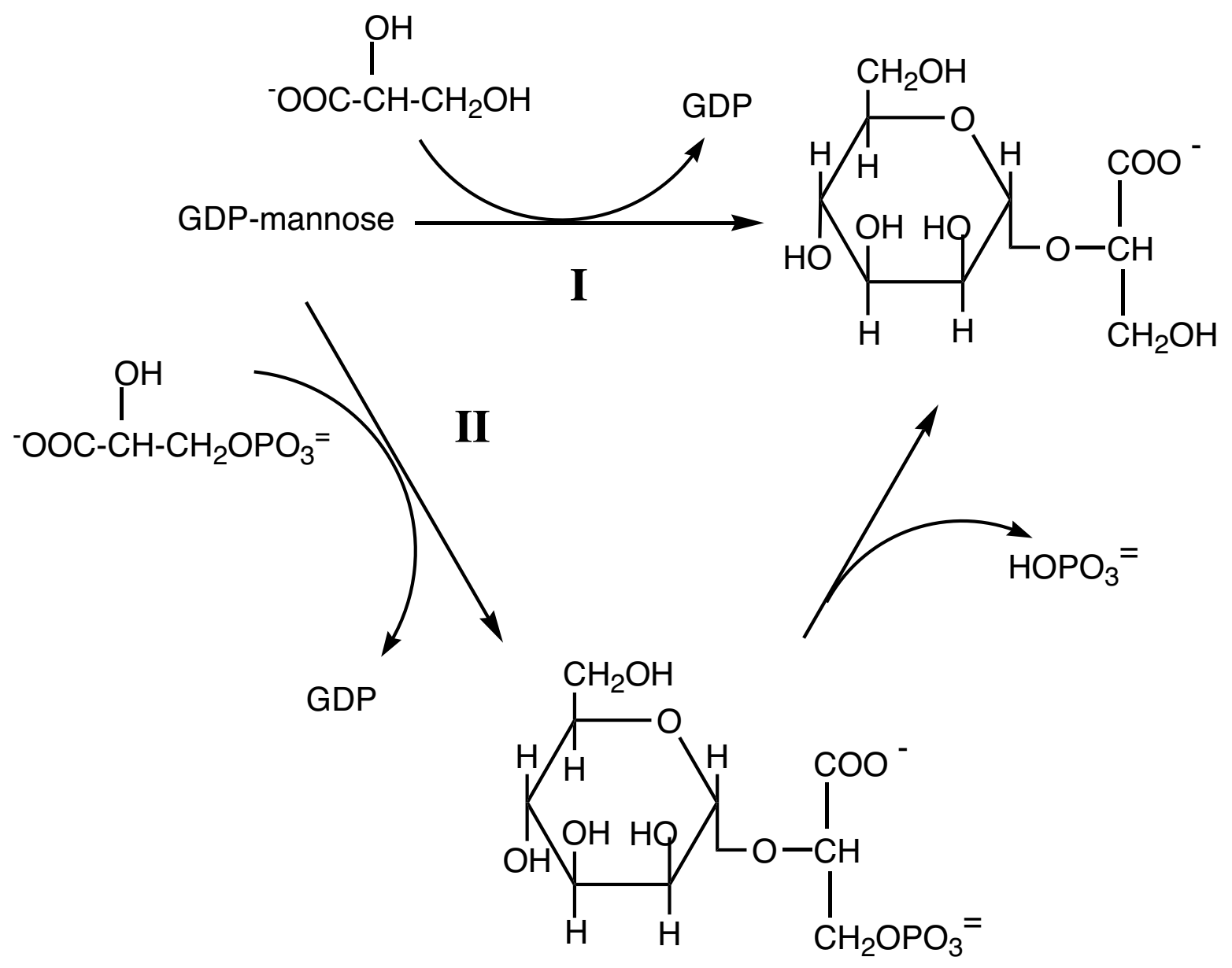

\section{Figure 9}

Two pathways exist for $\alpha$-mannosylglycerate biosynthesis. In (I) GDP-mannose is directly converted to mannosylglycerate. In (II), the GDP-mannose condenses with 3-phosphoglycerate to for mannosyl-3-phosphoglycerate, which is subsequently dephosphorylated to form mannosylglycerate.

proton motive force or sodium motive force to drive betaine accumulation, and (ii) ATP binding cassette (ABC) transporters that couple ATP hydrolysis to uptake.

Most organisms that internalize this solute do so via a member of betaine choline carnitine transporter (BCCT) family of secondary transporters [108]. The transporter can be quite specific for betaine as in the moderate halophilic lactic acid bacterium Tetragenococcus halophilus
[108] or Gram-positive Marinococcus halophilus [109]. Alternatively, the transporters available can internalize a wider range of solutes. For example, Listeria monocytogenes internalizes acetylcarnitine, carnitine, $\gamma$-butyrobetaine and 3-dimethylsulfoniopropionate as well as betaine, and the uptake increases the growth rate [110].

Other secondary transport systems have also been described. Corynebacterium glutamicum has the usual high 


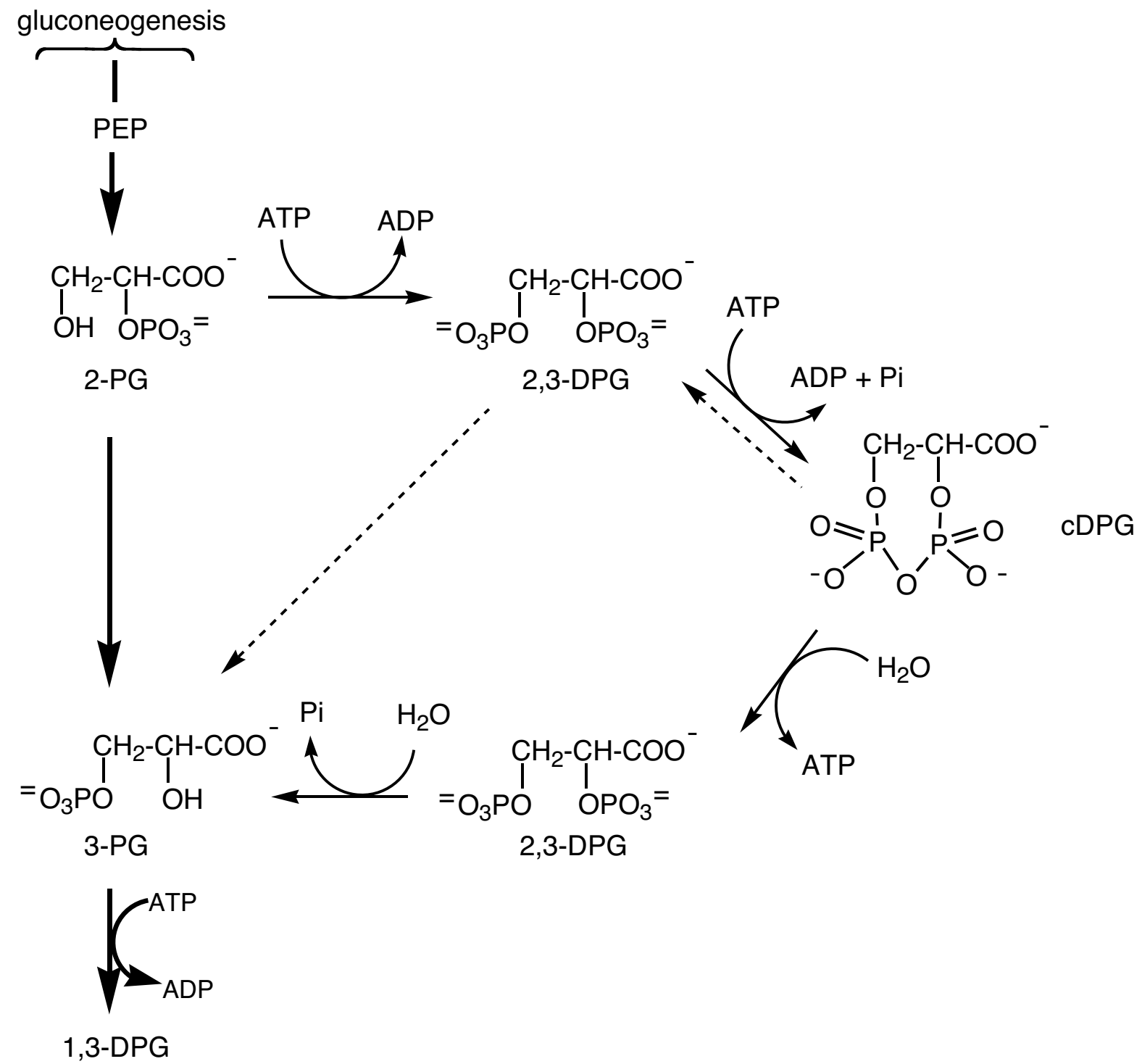

\section{Figure 10}

Proposed biosynthesis of cDPG as a pathway linked to gluconeogenesis through 2-PG and 3-PG. The dashed lines indicate the reversible cDPGS reaction of Methanothermus fervidus. The solid lines show cDPG and 2,3-DPG interconversions and illustrate the irreversible nature of the cDPGS in Methanobacter thermoautotrophicus.

affinity BetP uptake system. However, if this and the genes for three other compatible solute uptake systems are deleted, betaine can still be internalized, although the uptake is significantly reduced. The gene identified for the low capacity osmoregulated permease (lcoP) codes for a protein (LcoP) resembling a member of the BCCT-family
[111]. External osmolarity regulates expression and activity of LcoP.

Methanogens that can transport betaine into the cell tend to use a high affinity transporter [112] that is an $\mathrm{ABC}$ transporter. $\mathrm{ABC}$ betaine transporters have a nucleotide 
Table I: Halotolerant or halophilic microorganisms that can transport betaine or ectoinse from the medium.

\begin{tabular}{|c|c|c|}
\hline Solute \& Organism & Comments & Reference \\
\hline \multicolumn{3}{|l|}{ Betaine: } \\
\hline Acinetobacter sp. F-2-12 & in $20 \% \mathrm{NaCl}$, cells accumulate I.26 $\mathrm{M}$ betaine and $0.36 \mathrm{M}$ glutamate & {$[16]$} \\
\hline Actinopolyspora halophila & $\begin{array}{l}\text { cells can synthesize it de novo (oxidation of choline) as well as transport it from the } \\
\text { medium }\end{array}$ & {$[36]$} \\
\hline Alcaligenes sp. F-5-7 & $\sim \mathrm{M}$ betaine when cells grown in complex medium in $20 \% \mathrm{NaCl}$ & {$[16]$} \\
\hline Alteromonas sp. A-387 & & {$[16]$} \\
\hline Chromohalobacter israelensis & betaine in the medium suppresses ectoine biosynthesis & [26] \\
\hline Chromobacterium marismortui A-65 & in $20 \% \mathrm{NaCl}$, cells accumulate $0.5 \mathrm{M}$ betaine and $0.10 \mathrm{M}$ glutamate & {$[16]$} \\
\hline Corynebacterium glutamicum & $\begin{array}{l}\text { has genes for four uptake systems including high affinity BetP and a low capacity } \\
\text { osmoregulated permease }\end{array}$ & {$[111]$} \\
\hline Desulfovibrio halophilus & I mM external betaine suppresses sucrose synthesis & {$[37]$} \\
\hline Listeria monocytogenes & $\begin{array}{l}\text { halotolerant organism also accumulates acetylcarnitine, carnitine, } \gamma \text {-butyrobetaine and 3- } \\
\text { dimethylsulfoniopropionate }\end{array}$ & {$[110]$} \\
\hline Marinococcus halophilus & BCCT family transporter BetM & {$[109]$} \\
\hline Methanohalophilus portucalensis FDFI & $\begin{array}{l}\text { accumulation of external betaine suppresses synthesis of osmolytes; bta gene responsible } \\
\text { for } A B C \text { transporter activated by heat and salt stress }\end{array}$ & {$[8]$} \\
\hline Methanosarcina mazei Göl & ota gene responds to salt shock & [113] \\
\hline Methanosarcina thermophila TM-I & High affinity $A B C$ transporter & {$[112]$} \\
\hline Nesterenkonia halobia CCM 259I & in $20 \% \mathrm{NaCl}$, betaine is $1.10 \mathrm{M}$ while glutamate is $0.05 \mathrm{M}$ & {$[16]$} \\
\hline Pseudomonas sp. F-I2-I & & {$[16]$} \\
\hline Tetragenococcus halophilus & single component transporter (ButA) that is a member of BCCT family; specific for betaine & {$[108]$} \\
\hline Salinivibrio costicola A-5I4 & & {$[16]$} \\
\hline \multicolumn{3}{|l|}{ Ectoine: } \\
\hline Halomonas elongata & transporter similar to tripartite ATP-independent periplasmic transporter family (TRAP-T) & {$[116]$} \\
\hline Marinococcus halophilus & role likely to be recovery of leaked ectoine & {$[109]$} \\
\hline Sinorhizobium meliloti & $A B C$ ectoine transporter identified & {$[117]$} \\
\hline
\end{tabular}

binding domain that hydrolyzes ATP, a membrane spanning domain, and a substrate binding domain (and/ or a periplasmic or extracellular binding protein with a high affinity for betaine). The ota (osmoprotectant transporter $\underline{\mathrm{A}}$ ) gene of Methanosarcina mazei responds to salt shock [113]. Methanohalophilus portucalensis FDF1 can transport betaine into the cell as well as synthesize it de novo $[8,82]$. The bta gene responsible for betaine transport in this organism is also an $\mathrm{ABC}$-transporter and is activated by heat as well as salt stress [114]. It is highly specific for betaine - choline, proline and dimethylglycine, and carnitine could not compete with betaine uptake. Interestingly, addition of exogenous betaine or its biosynthetic intermediates induced bta expression immediately. The energy required for synthesis of betaine is 36 ATP whereas only two ATP are required for betaine transport by bta (S.-C. Chen and M.-C. Lai, unpublished results).

How does betaine finds the transporter? In hyperthermophiles, the high affinity ligand-binding protein ProX serves to bring the betaine to the transporter. Crystal structures of the A. fulgidus ProX in the absence and presence of betaine have identified cation- $\pi$ interactions and non-classical hydrogen bonds between protein and ligand [114]. Similar ligand binding domains have been identified in ORFs in the genomes of other archaea.

\section{B. Ectoine}

Ectoine that is provided in the medium can be internalized by some microorganisms. Growth of halotolerant Brevibacterium sp. JCM 6894 is stimulated by exogenous ectoine or hydroxyectoine [115]. In $H$. elongata the transporter for ectoine and hydroxyectoine (TeaA, TeaB, $\mathrm{TeaC}$ ) is similar to members of the tripartite ATP-independent periplasmic transporter family (TRAP-T) [116]. The $\mathrm{K}_{\mathrm{s}}$ (ect) is $21.7 \mu \mathrm{M}$, indicating a high affinity for external ectoine. The role of this transporter appears to be recovery of ectoine leaked from the cell. Marinococcus halophilus also can transport external ectoine. In this cell, the EctM gene product is a BCCT family member [108].

In the same vein, a proteomic analysis of Sinorhizobium meliloti in media that was supplemented with ectoine 
detected increased synthesis of ten proteins, eight of which were identified by MALDI-TOF analysis of peptides from the two-dimensional gels [117]. Five of these belong to the same gene cluster (localized on the pSymB megaplasmid), whose components code for the ATP-binding cassette transporter ehu (ectoine/hydroxyectoine uptake). Another cluster of genes (eutABCDE) would produce proteins capable of ectoine catabolism. The net result of exposing $S$. meliloti to ectoine is to enhance the production of proteins to internalize and use any of these molecules that escape the cell.

\section{Homologues of Transporter Genes}

Halobacterium salinarum has two ORFs upstream of transducer genes with significant homology to binding proteins for amino acids and compatible solutes [118]. Deletion mutants indicate that the CoSB/CosT binding/ transducer pair, in which the $\operatorname{Cos} B$ is a membraneanchored receptor, is critical for chemotaxis towards compatible solutes (in this case betaine). Whether or not the organism accumulates large amounts of betaine (which seems not to occur in Halobacterium NRC-1 [119]), this protein pair could function as a chemotaxis signaling pathway for organic osmolytes.

\section{D. $\boldsymbol{K}^{+}$}

A variety of $\mathrm{K}^{+}$channels have been identified in microorganisms. Structures of various $\mathrm{K}^{+}$channels, initially a closed, small bacterial channel [120] and more recently a gated $\mathrm{K}^{+}$-channel (MthK) from Methanobacter thermoautotrophicus [121], have contributed to understanding how these proteins are arranged in membranes. However, these $\mathrm{K}^{+}$-channels do not respond to altered osmotic pressure. Rather, different protein complexes appear to regulate intracellular $\mathrm{K}^{+}$in response to osmotic stress. $H$. elongata uses $\mathrm{K}^{+}$-glutamate as an osmolyte. Recent work has identified three genes required for $\mathrm{K}^{+}$uptake: trkA, $\operatorname{trkH}$, and trkI [122]. The protein expressed by trkA would be analogous to the cytoplasmic NAD $+\mathrm{NADH}$ binding protein TrkA in E. coli that is required for $\mathrm{K}^{+}$uptake by the Trk system, while the H. elongata TrkH and TrkI are likely to be transmembrane proteins. Experiments with $H$. elongata indicate the TrkI is the main $\mathrm{K}^{+}$-transporter in this organism. Similar uptake systems may exist in other halophiles as well.

\section{E. Membrane Osmosensors}

Cells will swell upon hypoosmotic shock as water rushes into the cell. To return to the original cell volume, cells need a rapid means of cytoplasmic solute efflux. All microorganisms have families of gated transmembrane channels that open for solute release when the lateral pressure of the membrane drops below a critical value (for review see [123]). Mechanosensitive channels (Msc) are gated by membrane tension and thought to be primary biosensors for osmoregulation in bacteria [124,125]. Their major role appears to be the rapid and non-discriminating release of solutes upon hypoosmotic shock [125]. Msc fall into three classes: MscL, a pentamer with no solute preference that has large conducting activity; $\mathrm{MscS}$, a heptamer that has smaller conductance, is sensitive to membrane tension, and can exhibit selectivity for anions or cations; MscK, likely a heptamer like MscS that is activated by cytoplasmic $\mathrm{K}^{+}$[123]. These channels are usually closed but upon changes in membrane tension can open to allow solute efflux. Other osmosensors include the Volume-activated channels (VAC). These have been suggested to respond to hypoosmotic response as anion channels [126]. VAC sensors appear to be responsible for the expulsion of a variety of osmolytes, notably amino acids and polyols.

\section{Macromolecule Stabilization By Osmolytes - Theories}

Along with balancing external osmotic pressure, compatible solutes have also been shown to stabilize macromolecules. There are many theories regarding protein-solute interactions. These can be classified into two types: (i) those that postulate direct solute-macromolecule interactions and (ii) those that hypothesize that macromolecular stability is mediated by solute-induced changes in water structure.

\section{A. Solute-Macromolecule Interactions: Preferential Solute Exclusion andHydration}

Osmolytes in high concentrations compete with water molecules for interactions with protein surfaces. However, it has been proposed that these organic solutes are preferentially excluded from the surface of proteins [127130]. This in turn leads to preferential hydration of the protein. The increased osmotic pressure generated by the solutes should favor compact folded proteins, which expose less surface area than denatured protein (Figure $11 \mathrm{~A}$ ). The size of internal cavities and internal water should be reduced as well [131]. Differential interactions of organic solutes with folded and denatured proteins also contribute to their stabilization effects. Bolen and coworkers [132] have proposed that, compared to water, solutes have more unfavorable interactions with the peptide backbone and since unfolded protein has more available backbone, this biases the equilibrium to a folded protein (Figure 11B). This would suggest that osmolytes that impart stability actually interact with the unfolded state of the protein, shifting the equilibrium to promote the folded configuration (the 'osmophobic effect' [132]). The free energy of the denatured state is higher than that of the native state, making population of this state energetically unfavorable (Figure 11B). Any interactions of osmolytes with hydrophobic residues of the unfolded 

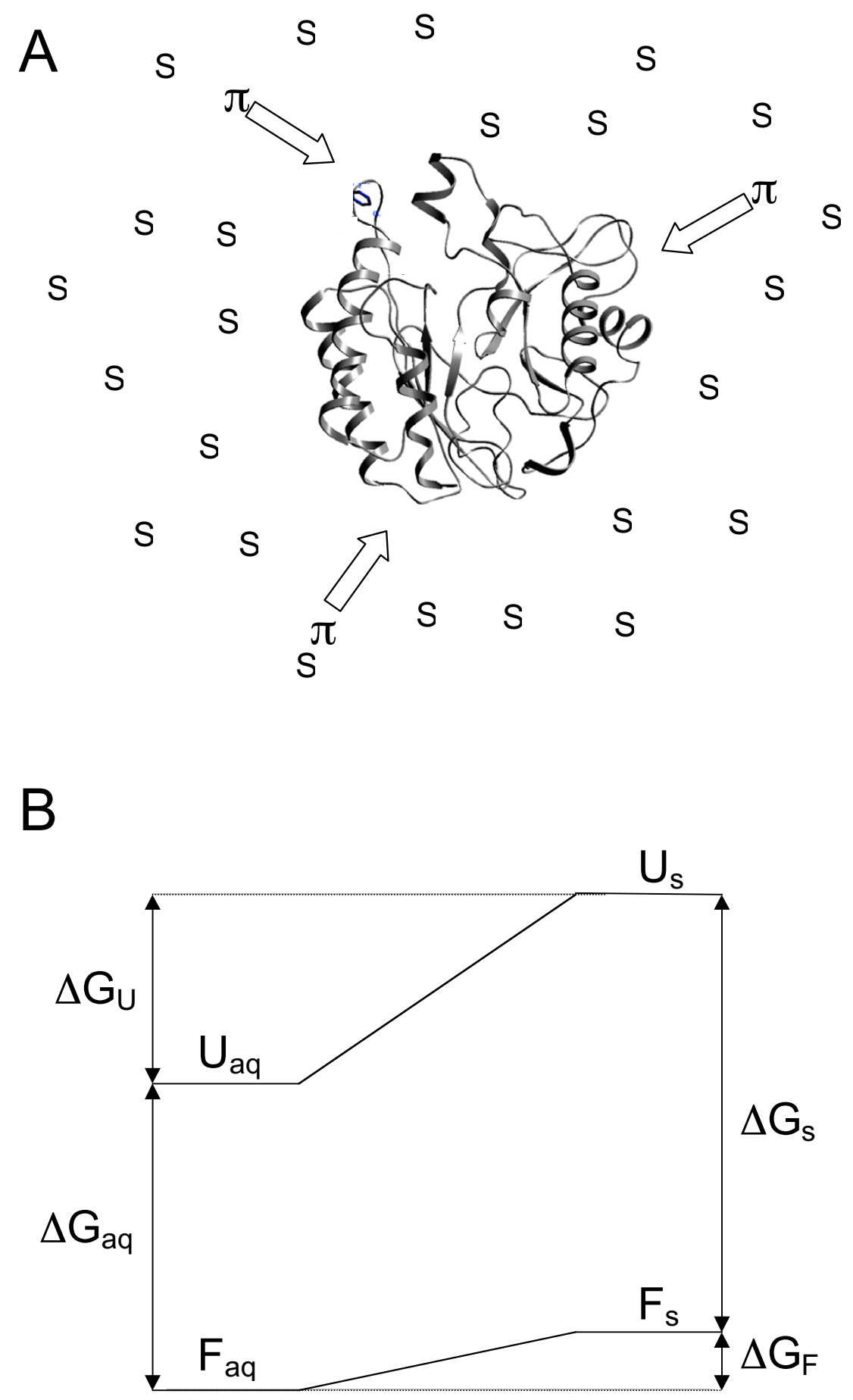

Figure II

(A) Exclusion of solutes from the surface of a protein increases the concentration of solute in the bulk solution, which in turn increases water surface tension generating osmotic pressure that drives a protein to retain a more compact structure. (B) Osmolytes stabilize proteins to thermal denaturation by differentially raising the energy level of the unfolded state: $U$, unfolded state; F, folded state; aq, aqueous solution; $\mathrm{S}$, solution containing osmolytes. 
protein do not overcome the osmophobic effect, nor do they interfere with the hydrophobic effect.

\section{B. Solute-Induced Changes in Water Structure}

Ionic solutes will have a pronounced effect on water structure and these interactions will affect macromolecule stability. Neutral salts do not have the same effect on structure and solubilities of proteins. The Hofmeister series of ions reflects the ability of different ions to bind water $[133,134]$. 'Kosmotropes' (order makers) exhibit a strong interaction with water, while 'chaotropes' (disorder makers) exhibit weaker interactions with water than water has with itself. It is thought that kosmotropes bind water strongly and aid in preserving the hydration layer around the macromolecules. These solutes prefer interactions with water rather than the protein surface, hence preserve preferential hydration of the protein. Chaotropes can displace water from the protein surface and contribute to destabilization of structure by dehydrating the macromolecule. Many osmolytes are strikingly similar to the ions of the Hofmeister series: amino acids resemble ammonium acetate and the methylamines are functionally similar to quarternary ammonium ions [135]. Their effects on proteins should then be similar to those in the Hofmeister series.

Collins and coworkers have shown that the Hofmeister series is actually a function of the apparent dynamic hydration number of the ion $[136,137]$, with the more hydrated an ion, the greater the stabilization of macromolecules. The calculated hydrated radius for each ion nicely coincides with the ionic strength. Collins postulated that the effect of an osmolyte on another solute (in this case the macromolecule) depends on the extent it perturbs the solvation layer of the other solute. If the osmolyte is tightly hydrated, it cannot as easily interact with the macromolecule solvation layer, an event that would destabilize the macromolecule.

Other considerations of water structure and the influence of solutes on charged regions of macromolecules have suggested that the water layer at the protein surface is more dense and reactive than bulk water [138]. Patches of dense water, along with counterions, would cover charged surface regions of the protein, while inert zones of lowdensity water would be found around hydrophobic groups. Macromolecular crowding (see below) would also influence this. In dilute solutions, changing the density of the bulk water would be energetically unfavorable because of the large relative volume. When the solution is concentrated (a cell typically has 2 to $4 \mathrm{~g}$ water/g dry weight [138]), the volume of surface water becomes comparable to the volume of bulk water, allowing density changes to occur.

\section{Osmolytes, Excluded Volume, and Pressure Effects}

The crowded and inhomogeneous environment of the cell also contributes to stabilization of folded proteins [139141]. The presence of solutes such as osmolytes, 'macrosolutes' such as cofactors, and other macromolecules aid in stabilizing proteins by decreasing the accessible volume, shifting the equilibrium between the folded and unfolded state of proteins to favor the more compact folded state.

This has relevance to pressure stress as well. Increasing hydrostatic pressure should promote water penetration from protein surface to the core. With osmolytes that are bigger than water, this penetration is less likely if critical water is around the protein and bulk water is diluted with the osmolyte. Studies of Photobacterium profundum solutes at 1 and 280 atm are perhaps the best evidence that small solutes can repel / inhibit water penetration at high hydrostatic pressures [52]. Elevated hydrostatic pressure tends to denature proteins [142], presumably by enhancing water penetration into the protein core [143]. In this deep sea organism, $\beta$-hydroxybutyrates accumulate to high intracellular levels at 280 atm. Perhaps these negatively charged solutes aid in preventing water penetration, both with an excluded volume effect but also by altering water structure in the vicinity of the proteins.

The observation of osmolyte cocktails in different types of cells likely reflects selection of solutes that cover different aspects of these effects - destabilization of the denatured state, retardation of water penetration in protein cores, and optimal modulation of water density for a particular cytoplasm. For example, one might expect thermophiles to have different solutes than mesophiles if solute exclusion is less important than other aspects of osmolyte effects (perhaps at high temperatures altering water structure is more important). The accumulation of multiple solutes may be explained by slightly different (and potentially overlapping) effects for each specific solute. For example, in a cell with multiple zwitterions, perhaps solute size or charge distribution are important in stabilizing water at some protein surfaces, while for other proteins preferential exclusion is the dominant effect. In cells with mixed zwitterions and anions, perhaps the anions are better excluded by proteins with a net negative charge, but if the organic anions are balanced by intracellular $\mathrm{K}^{+}$there may be a limit on their intracellular concentration and so zwitterions are also accumulated.

\section{Experimental Effects Of Osmolytes On Macromolecules}

\section{A. Thermoprotection of Proteins}

Heat stress often provokes similar responses to salt stress. Organisms adapt to high external salinity by accumulating osmolytes, and the same solutes accumulated in vivo 
can also affect stability of microorganisms to thermal stress. E. coli cells adapted to grow in high salt contain increased betaine. Diamant et al. [144] showed that heat shock of these salt-adapted cells dramatically reduces the protein aggregation seen in non-adapted cells under the same stress. This behavior was suggested to result from osmolyte (specifically betaine, glycerol, proline or trehalose) activation of chaperones GroEL, DnaK, and ClpB. While such interactions could be shown at low osmolyte levels, at high osmolyte levels, refolding of proteins was reduced, possibly because of specific deleterious interactions of the osmolytes with chaperones.

In many cases, these small molecules assist in protein stabilization and/or refolding in vitro. The in vitro studies with purified enzymes allow one to explore any protective effects or unusual behavior of novel compatible solutes. These studies are consistent with the hypothesis that osmolytes are selected for their unfavorable interactions with peptide backbones [132].

Rabbit muscle lactate dehydrogenase has been used to test the effect of ectoine, hydroxyectroine, and their biosynthetic precursors DA and NADA on thermostability of this enzyme. At $55^{\circ} \mathrm{C}$ NADA enhances thermostability as measured by protection of the enzyme from thermal inactivation [89]. Hydroxyectoine is more effective than ectoine and NADA at stabilizing proteins to heat stress. The one real difference with hydroxyectoine is a hydroxyl group on the ring. Perhaps this further functionalization of the (now trihydro)pyrimidine ring aids in organizing water and maintaining high surface tension at high temperatures.

Ribonuclease has been a popular target for osmolyte stabilization studies. This disulfide crosslinked enzyme can be reversibly unfolded in the absence of reducing agents. The effects of some of the more exotic osmolytes have been examined with this enzyme. 2-O- $\alpha$-Mannosylglycerate, $0.5 \mathrm{M}$, increases the mid-point of the thermal denaturation curve, $\mathrm{T}_{\mathrm{m}^{\prime}}$ by $7^{\circ} \mathrm{C}$ as well as increases the heat capacity for the protein [145], an effect consistent with the solute destabilizing the denatured state with respect to folded protein. Other studies with ribonuclease D show that a variety of zwitterionic osmolytes dramatically increase $\mathrm{T}_{\mathrm{m}}$ for the protein. As an example, $6 \mathrm{M}$ sarcosine increases $\mathrm{T}_{\mathrm{m}}$ by $24.6^{\circ}$ at $\mathrm{pH} 5$ [146]. Crystal structures of the ribonuclease fail to detect any bound osmolyte or alterations in water bound to the protein. The data support the hypothesis that osmolytes stabilize proteins by perturbing unfolded states, which biases the equilibrium to a compact, folded state.

The charge distribution of an osmolyte can be important to its biological activity as well. Solutes used by bacteria and archaea have not been examined since the pKa of any functional groups are well outside accessible $\mathrm{pH}$ ranges for maintaining native proteins. Trimethylamine $\mathrm{N}$-oxide (TMAO), a common solute in eukaryotes, is zwitterionic above pH 6 (pKa of 4.66), and it is this state of the molecule that is critical for its stabilization of proteins [147]. At low $\mathrm{pH}$ it no longer acts as a good thermoprotectant. While this observation may not have physiological relevance, it aids in our understanding of osmolyte properties important for their biological effects. TMAO has been shown to decrease the entropy of the unfolded state of onconase through a solvophobic effect [148]. This solute clearly diminishes the unfolding rate while having little effect on the stability of the native protein. For onconase, TMAO appears to induce a local structural change that retards unfolding.

The solute exclusion theory would argue for little specificity in osmolyte effects on macromolecules. However, there are many studies that clearly show preferential stabilization by solutes. Osmolytes can counteract denaturants such as urea. Potassium D- or L-glutamate (0.25 M) counteracts the effect of urea on glutaminyl-tRNA synthetase from Escherichia coli by shifting the equilibrium between the native and molten globule and molten globule to unfolded protein to a higher urea concentration [149]. However, for this protein other osmolytes (sorbitol, TMAO, inositol) cannot induce the same shift. A major conclusion of these studies is that the ability of an osmolyte to counteract urea denaturation depends on specific osmolyte-protein interactions.

As another example, two archaeal rubredoxins have been shown to be stabilized to quite different extents by $\alpha$-diglycerol phosphate [150]. Their structures are similar, except that one is missing a hairpin loop. There are small conformational changes induced by $\alpha$-DGP (or mannosylglycerate) and evidence for solute inducing a more compact state of the protein, and the occurrence of weak, specific interactions between osmolyte and protein surface.

Osmolytes can affect protein conformation and motions of native structures as well. TMAO induces $\alpha$-helix formation of alanine-base peptides [151]. Compatible solutes also attenuate structural fluctuations as measured by amide hydrogen-deuterium exchange rates [152-154]. Osmolytes certainly inhibit slow, large unfolding transitions, but they can also modulate fast exchange rates as well [155]. Tryptophan phosphorescence has been used to probe the flexibility of the native structure of azurin and a number of mutants [131]. The sugar dampens fluctuations only for loose internally hydrated macromolecules and those with thermally expanded conformations. The sucrose (and presumably other polyols) will shift the 
equilibrium of protein conformations to a more compact rigid form.

One of the interesting questions is whether or not solutes in halophiles stabilize proteins in the same manner as for nonhalophiles. An interesting case in point is the effect of $\mathrm{KCl}$ on the dihydrofolate rductase (DHFR) from Haloferax volcanii compared to that from E. coli [156]. The protein from the extreme halophile is much more acidic and one might think the stabilization effects by $\mathrm{K}^{+}$would differ compared to the mesophilic, non-halophilic homologue. The H. volcanii DHFR requires at least $0.5 \mathrm{M} \mathrm{KCl}$ to stay folded, while the E. coli protein is inactive above $1 \mathrm{M} \mathrm{KCl}$. Yet the effect of salts on the stability of the proteins to urea is similar, if one compares stability at the appropriate physiological ionic strength. This work shows that salts stabilize the DHFRs by a common mechanism preferential hydration and the Hofmeister effect of salt on the activity and entropy of the aqueous solvent. Although one could imagine hydrated salt networks occurring in the halophilic protein leading to halophile-specific stabilization, that is not the case.

\section{B. Interaction with Nucleic Acids}

Although most research into how osmolytes affect macromolecular stability has concentrated on proteins/ enzymes, these solutes also affect nucleic acid stability. The addition of high concentrations of zwitterionic solutes increases the dielectric constant of the solution that, in turn, decreases ionic interactions and affects the DNA duplex. Isolated studies have explored the effect of zwitterionic solutes on nucleic acid stability. For example, betaine has been shown to eliminate the dependence of dsDNA melting on the base pair composition [157] and to enhance amplification of GC-rich templates [158] by lowering the $\mathrm{T}_{\mathrm{m}}$ for the template. High concentrations of compatible solutes also alter accessibility of regions of the DNA to nucleases. Malin et al. [159] showed that ectoine and hydroxyectoine alter the DNA conformation such that endonucleases can no longer cleave it.

\section{Biotechnological Applications Of Osmolytes}

The properties of osmolytes make them suitable for a variety of uses in biotechnology as long as one can generate reasonable quantities either in vivo or in vitro. Induction of osmolytes in cells can increase protein folding, so that engineering osmolyte biosynthesis genes in an organism should improve its salt tolerance. The trick is to couple osmolyte production to salt stress. For in vitro uses, large amounts of pure solutes are needed. In many cases, the solutes can be supplied by 'bacterial milking.' Both ectoine and hydroxyectoine have been produced in large quantities using Halomonas elongata [160]. Bacteria in high $\mathrm{NaCl}$ are transferred to low osmolarity medium where they excrete the now excess solutes. Re-exposure of the bacteria to high salt induces them to re-synthesize the osmolytes. Repeated transfers between low and high osmolarity media should dramatically enrich the media in the osmolytes. Purification of the solutes then relies on chromatographic steps. This process is the basis of the German biotechnology company Bitop http:// www.bitop.de/sources/html/e/index.htm that has developed preparative methods for many of the unique osmolytes produced by microorganisms.

\section{A. Chemical Chaperones for Protein Folding}

Insoluble or misfolded overexpressed proteins can often be partially denatured and refolded in the presence of osmolytes. A specific example is the use of osmolytes to enhance the yield of folded, functional cytotoxic proteins directed to the periplasm of $E$. coli [161]. Cells grown in $4 \% \mathrm{NaCl}$ with $0.5 \mathrm{M}$ sorbitol and supplemented with 10 $\mathrm{mM}$ betaine can accumulate large amounts of the target protein in the periplasm (this was tried with immunotoxins). Protein is released by freeze-thaw cycles. Both high osmotic strength and added compatible solutes (in this case betaine and sorbitol) are necessary for high yields of protein.

In the same vein, ectoine, betaine, trehalose, and citrulline have been shown to inhibit insulin amyloid formation in vitro [162]. This observation may provide directions for designing small molecules to inhibit myelin formation associated with neurodegenerative disorders.

\section{B. Enhancing PCR}

Several osmolytes (notably betaine, ectoine) have been shown to be useful in PCR amplification of GC-rich (72.6\% GC) DNA templates with a high $\mathrm{T}_{\mathrm{m}}$. In particular, ectoine was shown to outperform regular PCR enhancers; it works by reducing the DNA $\mathrm{T}_{\mathrm{m}}$ [163]. Interestingly, hydroxyectoine increases the $\mathrm{T}_{\mathrm{m}}$ of duplex DNA. However, the optimal solute for these experiments is homoectoine (4,5,6,7-tetrahydro-2-methyl-1H-[1,3]-diazepine-4-carnoic acid), a synthetic derivative of ectoine with the ring expanded by one carbon. For betaine the effective range of solute is 0.5 to $2.0 \mathrm{M}$; for ectoine much less $(0.25$ to 0.5 $\mathrm{M}$ ) is needed for the same effect. It would be intriguing to see what effect DIP type solutes have on PCR since they are synthesized by hyperthermophiles above $80^{\circ} \mathrm{C}$.

\section{Cryo-protection of microorganisms}

Organic osmolytes have also been used as cryo-protectants. In a recent study, the ability of betaine to act as a cryo-protectant during freezing of diverse bacteria was examined. Betaine is often much better than two common cryo-protectant mixtures, serum albumin and trehalose/ dextran, particularly under conditions simulating longterm storage [164]. It is better than the other treatments at preserving long term viability for microorganisms like 
Neisseria gonorrhoeae and Streptococcus pneumoniae. Betaine is as effective as glycerol for liquid nitrogen freezing of halophilic archaea, and neutrophilic Fe-oxidizing bacteria.

\section{Use in cosmeceuticals and pharmaceuticals}

The ability of osmolytes to aid in protecting cells from diverse stresses has led to the use of at least one of them, ectoine, in the cosmeceutical industry. Ectoine has been shown to protect skin from UVA-induced cell damage [65]. Based on this, RonaCare ${ }^{\mathrm{TM}}$ Ectoin, produced by Merck KgaA, Darmstadt, is presently in use as a moisturizer in cosmetics and skin care products.

Osmolytes have not been developed as reagents in the pharmaceutical industry, in part because as 'compatible solutes' they interact minimally with cellular machinery. However, their ability to stabilize biomolecules may have some very specific uses. As an example, the German company Bitop in collaboration with researchers at the Cologne University Clinic is exploring the use of these solutes in certain cancer therapies where they may protect tissues against vascular leak syndrome, a severe side effect of anti-caner agents.

\section{E. Generation of Stress-Resistant Transgenic Organisms} Insertion of genes for osmolytes into non-halotolerant organisms should increase their ability to withstand salt stress. Plants are a good target for these types of experiments since they are often exposed to drought conditions that would concentrate salt. A few reports of transgenic plants suggest that eventually this strategy might be useful. Arabidopsis thaliana transformed with a choline oxidase gene (which is needed to synthesize betaine) from Arthrobacter globiformis has a significantly improved tolerance of salt stress along with improved cold and heat tolerance [166]. Transgenic tobacco with E. coli betA and bet $B$ genes has also been constructed. This modified plant exhibits better salt and cold tolerance [167]. Inserting the $H$. elongata ectABC genes also confers hyperosmotic tolerance on cultured tobacco cells [168]. This was shown to increase the hyperosmotic tolerance of cultured cells, although only a small amount of ectoine accumulated. Other recent work to introduce genes for synthesizing osmolytes in plants [169] as a way to improve stress tolerance has, so far, not led to high accumulation of the osmolytes. Further developments await a determination of what limits osmolyte levels in plant cells.

\section{Conclusion}

Clearly, there are many different organic solutes used for osmotic balance in halotolerant and halophilic microorganisms [170]. Except for $\alpha$-glutamate, the solutes that are accumulated are not intermediates in biochemical pathways. They are appropriately modified so that they are not chemically reactive even if they occur at high concentrations (i.e., no reactive groups in carbohydrates) and would have little affinity for the macromolecules that interact with precursors. In most cases these organic solutes are not metabolized by the cells that accumulate them. With these properties, they nicely fulfill Brown's original definition of a compatible solute. However, some of the more uncommon solutes raise interesting questions. For example, what is it about DIP that makes it a solute of choice in hyperthermohiles growing above $80^{\circ} \mathrm{C}$ ?

One of the recurrent themes is that most microorganisms use a cocktail of solutes unless an external solute such as betaine is provided. One solute may be the major species, but there are usually several solutes at moderate concentrations in a cell, and the balance among the solutes can be modulated by growth stage and carbon and nitrogen substrates. In several of the cases described, there is a switch from one type of solute to another with increasing external $\mathrm{NaCl}$. The most common change is from anionic organic solutes to neutral or zwitterionic solutes (e.g. glutamates to $\mathrm{N} \varepsilon$-acetyl- $\beta$-lysine in several methanogens, $\alpha$-mannosylglycerate to $\alpha$-mannosylglyceramide in Rhodothermus marinus). This suggests that internal cation concentrations are intimately linked with the osmolyte pools. There is also evidence that when challenged with increased external $\mathrm{NaCl}$, many organisms exhibit an initial response, which in terms of solutes may include $\mathrm{K}^{+}$ internalization and $\alpha$-glutamate synthesis. The solutes in this first response are then replaced by a steady-state of other solutes reflecting the adapted cell osmolyte composition. How the cell coordinates this is an area that certainly needs to be explored.

In the past decade there has been significant progress in defining biosynthetic pathways and in identifying the enzyme components for many of these solutes. Ectoine, betaine, and mannosylglycerate synthesis have been examined in detail in several cells. Recent work has at least identified the genes coding for the lysine aminomutase and acetyltransferase needed for $\mathrm{N} \varepsilon$-acetyl- $\beta$-lysine biosynthesis, and several of the enzymes along the biosynthetic pathways for $\beta$-glutamate and DIP have been characterized. Yet the enzymes responsible for the synthesis of other solutes (notably the neutral dipeptide and derivatized amino acid, $\alpha$-diglycerol phosphate, and sulfotrehalose) have not been explored. In order to understand how external $\mathrm{NaCl}$ concentrations are linked to osmolyte synthesis (or removal) such information is critical.

Significant work has also been carried out to understand the thermoprotective features of osmolytes. It has become clear that solutes can have specific effects on protein 
dynamics and appear to limit some types of motions with the net result of stabilizing folded rather than unfolded structures. As more examples appear we should have a better idea of some of the unusual properties of some osmolytes. For example, modified polyols and carbohydrates are often used by cells that grow at high temperatures as well as high salt. Do these solutes alter solvent structure in a uniform way? Are they better than other solutes in aiding as chemical chaperones for protein folding/ refolding?

Regardless of the details of osmolyte biosynthesis and interactions, it is clear that there is a use for these solutes in the biotechnology arena. Stabilization of proteins or enhancing PCR is an obvious application of these solutes, and only the most common solutes have been tried thus far. One might even improve upon the natural solutes with synthetic molecules if one has a firm grasp of how they affect different systems. Some of the more unusual solutes may have particularly interesting properties that could be exploited either in vitro or in vivo. Engineering foreign osmolyte pathways into other cells has not been very successful but such transgenic organisms will certainly be optimized in the future. It will certainly be interesting to see what new information is provided in the next 5 years or so.

\section{Competing interests}

The author(s) declare that they have no competing interests.

\section{Acknowledgements}

Preparation if this review was supported in part by a grant from the Department of Energy Biosciences DE-FG02-9IER20025.

\section{References}

I. Galinski EA: Osmoadaptation in bacteria. Adv Microb Physiol 1995, 37:272-328.

2. Martin DD, Ciulla RA, Roberts MF: Osmoadaptation in archaea. Appl Environ Microbiol 1999, 65:1815-1825.

3. Roberts MF: Osmoadaptation and osmoregulation in archaea: update 2004. Front Biosci 2004, 9:1999-2019.

4. Brown AD: Microbial water stress. Bacteriol Rev 1976, 40:803-846.

5. Galinski EA, Pfeiffer HP, Trüper HG: 1,4,5,6-Tetrahydro-2methyl-4-pyrimidinecarboxylic acid. A novel cyclic amino acid from halophilic phototrophic bacteria of the genus Ectothiorhodospira. Eur J Biochem 1985, I49:135-139.

6. Robertson DE, Lesage $S$, Roberts MF: $\beta$-Aminoglutaric acid is a major soluble component of Methanococcus thermolithotrophicus. Biochim Biophys Acta 1989, 992:320-326.

7. Sowers KR, Robertson DE, Noll D, Gunsalus RP, Roberts MF: $\mathbf{N} \varepsilon-$ acetyl- $\beta$-lysine: an osmolyte synthesized by methanogenic bacteria. Proc Natl Acad Sci USA 1990, 87:9083-9087.

8. Lai MC, Sowers KR, Robertson DE, Roberts MF, Gunsalus RP: Distribution of compatible solutes in the halophilic methanogenic archaebacteria. J Bacteriol 1991, 173:5352-5358.

9. Scholz S, Sonnenbichler J, Schäfer W, Hensel R: Di-myo-inositolI, I'-phosphate: a new inositol phosphate isolated from Pyrococcus woesei. FEBS Lett 1992, 306:239-242.

10. Ciulla R, Burggraf S, Stetter KO, Roberts MF: Occurrence and role of di-myo-inositol-I,I'-phosphate in Methanococcus igneus. Appl Environ Microbiol 1994, 60:3660-3664.
II. Fan TW-M: Metabolite profiling by one and two-dimensional NMR analysis of complex mixtures. Progr Nucl Magn Res Spec 1997, 28:161-219.

12. Motta A, Romano I, Gambacorta A: Rapid and sensitive NMR method for osmolyte determination. J Microbiol Methods 2004, 58:289-294.

13. Kets EPW, de Bont JAM, Heipieper HJ: Physiological response of Pseudomonas putida $S \mid 2$ subjected to reduced water activity. FEMS Microbiol Lett 1996, I39:133-137.

14. Kunte HJ, Galinski EA, Trüper HG: A modified FMOC-method for the detection of amino acid-type osmolytes and tetrahydropyrimidines (ectoines). I Microbiol Methods 1993, 17:129-136.

15. Riis V, Maskow T, Babel W: Highly sensitive determination of ectoine and other compatible solutes by anion-exchange chromatography and pulsed amperometric detection. Anal Bioanal Chem 2003, 377:203-207.

16. Imhoff JF, Rodriguez-Valera F: Betaine is the main compatible solute of halophilic eubacteria. J Bacteriol 1984, 160:478-479.

17. Robertson DE, Noll D, Roberts MF, Menaia JA, Boone DR: Detection of the osmoregulator betaine in methanogens. Appl Environ Microbiol 1990, 56:563-565.

18. Nyyssölä A, Kerovuo J, Kaukinen P, von Weymarn N, Reinikaiuem T: Extreme halophiles synthesize betaine from glycine by methylation. J Biol Chem 2000, 275:22196-2220I.

19. Canovas D, Vargas C, Csonka LN, Ventosa A, Nieto J]: Synthesis of glycine betaine from exogenous choline in the moderately halophilic bacterium Halomonas elongata. Appl Environ Microbiol 1998, 64:4095-4097.

20. Roberts MF, Lai MC, Gunsalus RP: Biosynthetic pathway of the osmolytes $\mathrm{N} \varepsilon$-acetyl- $\beta$-lysine, $\beta$-glutamine, and betaine in Methanohalophilus strain FDFI suggested by nuclear magnetic resonance analyses. J Bacteriol 1992, 174:6688-6693.

21. Ciulla RA, Diaz MR, Taylor BF, Roberts MF: Organic osmolytes in aerobic bacteria from Mono Lake, an alkaline, moderately hypersaline environment. Appl Environ Microbiol 1997, 63:220-226.

22. Doronina NV, Trotsenko YA, Tourova TP: Methylarcula marina gen. nov., sp. nov. and Methylarcula terricola sp. nov.: novel aerobic, moderately halophilic, facultatively methylotrophic bacteria from coastal saline environments. Int J Syst Evol Microbiol 2000, 50: 1849-1859.

23. Doronina NV, Darmaeva TD, Trotsenko YA: Methylophaga alcalica sp. nov., a novel alkaliphilic and moderately halophilic, obligately methylotrophic bacterium from an East Mongolian saline soda lake. Int / Syst Evol Microbiol 2003, 53:223-229.

24. Kuhlmann AU, Bremer $\mathrm{E}$ : Osmotically regulated synthesis of the compatible solute ectoine in Bacillus pasteurii and related Bacillus spp. Appl Environ Microbiol 2002, 68:772-783.

25. Onraedt A, Walcarius B, Soetaert W, Vandamme E): Dynamics and optimal conditions of intracellular ectoine accumulation in Brevibacterium sp. Commun Agric Appl Biol Sci 2003, 68:24I-246.

26. Regev R, Peri I, Gilboa H, Avi-Dor Y: ${ }^{13}$ C NMR study of the interrelation between synthesis and uptake of compatible solutes in two moderately halophilic eubacteria, Bacterium Bal and Vibro costicola. Arch Biochem Biophys 1990, 278:106-II 2.

27. Onraedt A, De Muynck C, Walcarius B, Soetaert W, Vandamme E: Ectoine accumulation in Brevibacterium epidermis. Biotechnol Lett 2004, 26: |48|-| 485.

28. Pflughoeft KJ, Kierek K, Watnick PI: Role of ectoine in Vibrio cholerae osmoadaptation. Appl Environ Microbiol 2003, 69:5919-5927.

29. Sowers KR, Gunsalus RP: Halotolerance in Methanosarcina spp.: role of $\mathrm{N} \varepsilon$-acetyl- $\beta$-lysine, $\beta$-glutamate, glycine betaine and $\mathrm{K}^{+}$as compatible solutes for osmotic adaptation. Appl Environ Microbiol 1995, 6 I:4382-4388.

30. Robertson DE, Lai M-C, Gunsalus RP, Roberts MF: Composition, variation, and dynamics of major compatible solutes in Methanohalophilus strain FDFI. Appl Environ Microbiol 1992, 58:2438-2443.

31. Robertson DE, Noll D, Roberts MF: Free amino acid dynamics in marine methanogens. $\beta$-Amino acids as compatible solutes. J Biol Chem 1992, 267: I4893-1490I.

32. Borowitzka LJ, Brown AD: The salt relations of marine and halophilic species of the unicellular green alga, Dunaliella. The role of glycerol as a compatible solute. Arch Mikrobiol I974, 96:37-52. 
33. Petrovic U, Gunde-Cimerman N, Plemenitas A: Cellular responses to environmental salinity in the halophilic black yeast Hortaea werneckii. Mol Microbiol 2002, 45:665-672.

34. Silva Z, Borges N, Martins LO, Wait R, da Costa MS, Santos H: Com bined effect of the growth temperature and salinity of the medium on the accumulation of compatible solutes by Rhodothermus marinus and Rhodothermus obamensis. Extremophiles 1999, 3:163-72.

35. Roder A, Hoffmann E, Hagemann M, Berg G: Synthesis of the compatible solutes glucosylglycerol and trehalose by saltstressed cells of Stenotrophomonas strains. FEMS Microbiol Lett 2005, 243:219-226.

36. Nyyssölä A, Leisola M: Actinopolyspora halophila has two separate pathways for betaine synthesis. Arch Microbiol 200I, 176:294-300.

37. Welsh DT, Lindsay YE, Caumette P, Herbert RA, Hannan J: Identification of trehalose and glycine betaine as compatible solutes in the moderately halophilic sulfate reducing bacterium, Desulfovibrio halophilus. FEMS Microbiol Lett 1996, I 40:203-207.

38. Reed RH, Borowitzka LJ, Mackay MA, Chudek JA, Foster R, Warr SRC, Moore DJ, Steart WDP: Organic solute accumulation in osmotically stressed cyanobacteria. FEMS Microbiol Rev 1986 39:51-56.

39. Lunn JE, Price GD, Furbank RT: Cloning and expression of a prokaryotic sucrose-phosphate synthase gene from the cyanobacterium Synechocystis sp. PCC 6803. Plant Mol Biol 1999, 40:297-305.

40. Deplats P, Folco E, Salerno GL: Sucrose may play an additional role to that of an osmolyte in Synechocystis sp.PCC 6803 saltshocked cells. Plant Physiol Biochem 2005, 43: I33-I38.

4I. Lunn JE: Evolution of sucrose synthesis. Plant Physiol 2002, I 28: 1490-1500.

42. Mikkat S, Hagemann M, Schnoor A: Active transport of glucosylglycerol is involved in salt adaptation of he cyanobacterium Synechocystis sp. strain PCC 6803. Microbiology 1996, | 42: |725-1732.

43. Curatti L, Porchia AC, Herrera-Estrella L, Salerno GL: A prokaryotic sucrose synthase gene (susA) isolated from a filamentous nitrogen-fixing cyanobacterium encodes a protein similar to those of plants. Planta 2000, 2 I I:729-735.

44. Galinski EA, Oren A: Isolation and structure determination of a novel compatible solute from the moderately halophilic purple sulfur bacterium Ectothiorhodospira marismortui. Eur J Biochem I99I, I 98:593-598.

45. Smith LT, Smith GM: An osmoregulated dipeptide in stressed Rhizobium meliloti. J Bacteriol 1989, I 7 I:47|4-47।7.

46. D'Souza-Ault MR, Smith LT, Smith GM: Roles of N-acetylglutaminylglutamine amide and glycine betaine in adaptation of Pseudomonas aeruginosa to osmotic stress. Appl Environ Microbiol 1993, 59:473-478.

47. Roberts MF, Choi BS, Robertson DE, Lesage S: Free amino acid turnover in methanogens measured by ${ }^{15} \mathbf{N}$ NMR spectroscopy. J Biol Chem 1990, 265: I8207-I82I2.

48. Martin DD, Ciulla RA, Robinson PM, Roberts MF: Switching osmolyte strategies: response of Methanococcus thermolithotrophicus to changes in external $\mathbf{N a C l}$. Biochim Biophys Acta 200I, I 524: I-10.

49. Robertson DE, Roberts MF, Belay N, Stetter KO, Boone DR: Occurrence of $\beta$-glutamate, a novel osmolyte, in marine methanogenic bacteria. Appl Environ Microbiol 1990, 56:1504-I508.

50. Ciulla RA, Roberts MF: Effects of osmotic stress on Methanococcus thermolithotrophicus: ${ }^{13} \mathrm{C}$-edited 'H-NMR studies of osmolyte turnover. Biochim Biophys Acta 1999, I427:193-204.

51. DasSarma S, Arora P: Halophiles. In Encyclopedia of Life Sciences Volume 8. Nature Publishing Group; 2002:458-466

52. Martin DD, Bartlett DH, Roberts MF: Solute accumulation in the deep-sea bacterium Photobacterium profundum. Extremophiles 2002, 6:507-5I4.

53. Lamosa P, Burke A, Peist R, Huber R, Liu MY, Silva G, Rodrigues-Pousada C, LeGall J, Maycock C, Santos H: Thermostabilization of proteins by diglycerol phosphate, a new compatible solute from the hyperthermophile Archaeoglobus fulgidus. Appl Environ Microbiol 2000, 66:1974-1979.

54. Lamosa P, Martins LO, da Costa MS, Santos H: Effects of temperature, salinity, and medium composition on compatible sol- ute accumulation by Thermococcus spp. Appl Environ Microbiol 1998, 64:359|-3598.

55. Martins LO, Carreto LS, da Costa MS, Santos H: New compatible solutes related to di-myo-inositol-phosphate in members of the order Thermotogales. J Bacteriol 1996, I 78:5644-565I.

56. Da Costa MS, Santos H, Galinski EA: An overview of the role and diversity of compatible solutes in Bacteria and Archaea. Adv Biochem Eng Biotechnol 1998, 6 I: I I7-153.

57. Santos H, da Costa MS: Compatible solutes of organisms that live in hot saline environments. Environ Microbiol 2002, 4:501-509.

58. Martins LO, Huber R, Huber H, Stetter KO, da Costa MS, Santos $\mathrm{H}$ : Organic solutes in hyperthermophilic Archaea. Appl Environ Microbiol 1997, 63:896-902

59. Kanodia S, Roberts MF: Methanophosphagen: unique cyclic pyrophosphate isolated from Methanobacterium thermoautotrophicum. Proc Natl Acad Sci USA 1983, 80:52 I7-522I.

60. Seeley RJ, Farney DE: A novel diphospho-P, $\mathbf{P}^{\prime}$-diester from Methanobacterium thermoautrophicum. I Biol Chem 1983, 258:10835-10838.

6I. Ciulla R, Clougherty C, Belay N, Krishnan S, Zhou C, Byrd D, Roberts MF: Halotolerance of Methanobacterium thermoautotrophicum $\Delta \mathbf{H}$ and Marburg. I Bacteriol 1994, I 76:3 I77-3 I87.

62. Tolman CJ, Kanodia S, Daniels L, Roberts MF: ${ }^{3}$ I P NMR spectra of methanogens: 2,3-cyclophosphoglycerate is detectable only in methanobacteria strains. Biochim Biophys Acta 886:345-352.

63. Gorkovenko A, Roberts MF: Cyclic 2,3-diphosphoglycerate as a component of a new branch in gluconeogensis in Methanobacterium thermoautotrophicum $\Delta \mathbf{H}$. I Bacteriol 1993, I 75:4087-4095.

64. Evans JNS, Tolman CJ, Kanodia S, Roberts MF: 2,3-Cyclopyrophosphate in methanogens: evidence by ${ }^{13} \mathrm{C}$ NMR spectroscopy for a role in carbohydrate metabolism. Biochemistry 1985 , 24:5693-5698.

65. Desmarais D, Jablonski PE, Fedarko NS, Roberts MF: 2-Sulfotrehalose, a novel osmolyte in haloalkaliphilic archaea. J Bacterio $1997,179.3146-3153$.

66. Domenech P, Reed MB, Dowd CS, Manea C, Kaplan G, Barry CE: The role of MmpL8 in sulfatide biogenesis and virulence of Mycobacterium tuberculosis. J Biol Chem 2004, 279:2। 257-2 I 265.

67. Oren A: Diversity of halophilic microorganisms: environments, phylogeny, physiology, and applications. J Ind Microbiol Biotechnol 2002, 28:56-63.

68. Oren A, Heldal M, Norland S, Galinski EA: Intracellular ion and organic solute concentrations of the extremely halophilic bacterium Salinibacter ruber. Extremophiles 2002, 6:49I-498.

69. Ventosa A, Nieto J], Oren A: Biology of moderately halophilic aerobic bacteria. Microbiol Mol Biol Rev 1998, 62:504-544.

70. Rengpipat S, Lowe SE, Zeikus JG: Effect of extreme salt concentrations on the physiology and biochemistry of Halobacteroides acetoethylicus. I Bacteriol 1988, I 70:3065-307I.

7I. Heldal M, Norland S, Erichsen ES, Bratbak G, Sandaa RA, Larsen A, Thingstad F: Carbon limited marine bacteria keep high internal $\mathrm{Mg}^{2+}$ concentrations. submitted for publication; 2005 .

72. Müller V, Oren A: Metabolism of chloride in halophilic prokaryotes. Extremophiles 2003, 7:261-266.

73. Ede SM, Hafner LM, Fredericks PM: Structural changes in the cells of some bacteria during population growth: a Fourier transform infrared-attenuated total reflectance study. Appl Spectrosc 2004, 58:317-322.

74. Robinson PM, Roberts MF: Effects of osmolyte precursors on the distribution of compatible solutes in Methanohalophilus portucalensis. Appl Environ Microbiol 1997, 63:4032-4038.

75. Rozwadowski KL, Khachatourians GG, Selvaraj G: Choline oxidase, a catabolic enzyme in Arthrobacter pascens, facilitates adaptation to osmotic stress in Escherichia coli. J Bacteriol 1991, I 73:472-478.

76. Rathinasabapthi B, Burnet M, Russell BL, Gage DA, Liao PC, Nye G], Scott $P$, Golbeck JH, Hanson AD: Choline monooxygenase, an unusual iron-sulfur enzyme catalyzing the first step of glycine betaine synthesis in plants: prosthetic group characterization and cDNA cloning. Proc Natl Acad Sci USA 1997 94:3454-3458.

77. Andresen PA, Kaasen I, Styrvold OB, Boulnois G, Strom AR: Molecular cloning, physical mapping and expression of the bet 
genes governing the osmoregulatory choline-glycine betaine pathway of Escherichia coli. J Gen Microbiol 1988, I34:1737-1746.

78. Russell R, Scopes RK: Use of hydrophobic chromatography for purification of the membrane-located choline dehydrogenase from a Pseudomonas strain. Bioseparation 1994, 4:279-284.

79. Gadda G, McAllister-Wilkins EE: Cloning, expression, and purification of choline dehydrogenase form the moderate halophile Halomonas elongata. Appl Environ Microbiol 2003, 69:2126-2132

80. Nyyssölä A, Reinikaiuem T, Leisola M: Characterization of glycine sarcosine $\mathbf{N}$-methyltransferase and sarcosine dimethylglycine N-methyltransferase. Appl Environ Microbiol 2001, 67:2044-2050

8I. Waditee R, Tanaka Y, Aoki K, Hibino T, jikuya H, Takano J, Takabe T, Takabe $\mathrm{T}$ : Isolation and functional characterization of $\mathbf{N}$ methyltransferases that catalyze betaine synthesis from glycine in a halotolerant photosynthetic organism Aphanothece halophytica. J Biol Chem 2003, 278:4932-49432.

82. Lai M-C, Yang D-R, Chuang M-J: Regulatory factors associated with synthesis of the osmolyte glycine betaine in the halophilic methanoarchaeon Methanohalophilus portucalensis. Appl Environ Microbiol 1999, 65:828-833.

83. Peters $P$, Galinski EA, Trüper HG: The biosynthesis of ectoine FEMS Microbiol Lett 1990, 71:157-162.

84. Canovas D, Vargas C, Iglesias-Guerra F, Csonka LN, Rhodes D, Ventosa A, Nieto J]: Isolation and characterization of salt-sensitive mutants of the moderate halophile Halomonas elongata and cloning of the ectoine synthesis genes. J Biol Chem 1997 272:25794-2580I.

85. Canovas D, Vargas C, Calderon MI, Ventosa A, Nieto JJ: Characterization of the genes for the biosynthesis of the compatible solute ectoine in the moderately halophilic bacterium Halomonas elongata DSM 3043. Syst Appl Microbiol 1998, 2 I:487-497.

86. Ono H, Sawada K, Khunajakr N, Tao T, Yamamoto M, Hiramoto M, Shinmyo A, Takano M, Murooka Y: Characterization of biosynthetic enzymes for ectoine as a compatible solute in a moderately halophilic eubacterium, Halomonas elongata. Bacteriol 1999, 181:91-99.

87. Calderon MI, Vargas C, Rojo F, Iglesias-Guerra F, Csonka LN, Ventosa $\mathrm{A}$, Nieto JJ: Complex regulation of the synthesis of the compatible solute ectoine in the halophilic bacterium Chromohalobacter salexigens DSM 3043T. Microbiol 2004 I 50:305I-3063.

88. Louis P, Galinski EA: Characterization of genes for the biosynthesis of the compatible solute ectoine from Marinococcus halophilus and osmoregulated expression in Escherichia coli. Microbiology 1997, | 43: | |4|-| | 49.

89. Canovas D, Borges N, Vargas C, Ventosa A, Nieto J], Santos H: Role of $\mathbf{N} \gamma$-acetyldiaminobutyrate as an enzyme stabilizer and an intermediate in the biosynthesis of hydroxyectoine. Appl Environ Microbiol 1999, 65:3774-3779.

90. Pflüger K, Baumann S, Gottschalk G, Lin W, Santos H, Müller V: Lysine-2,3-aminomutase and $\beta$-lysine acetyltransferase genes of methanogenic archaea are salt induced and are essential for the biosynthesis of $N \varepsilon$-acetyl- $\beta$-lysine and growth in high salinity. Appl Environ Microbiol 2003, 69:6047-6055.

91. Robinson P, Neelon K, Schreier HJ, Roberts MF: $\beta$-Glutamate as a substrate for glutamine synthetase. Appl Environ Microbiol 200I, 67:4458-4463.

92. Chen L, Spiliotis ET, Roberts MF: Biosynthesis of di-myo-inositol$\mathrm{I}, \mathrm{I}$ '-phosphate, a novel osmolyte in hyperthermophilic archaea. J Bacteriol 1998, 180:3785-3792.

93. Scholz S, Wolff S, Hensel R: The biosynthesis pathway of di-myoinositol-I, I'-phosphate in Pyrococcus woesei. FEMS Microbiol Lett 1998, 168:37-42.

94. Stec B, Yang H, Johnson KA, Chen L, Roberts MF: MJOIO9 is an enzyme that is both an inositol monophosphatase and the 'missing' archaeal fructose-I,6-bisphosphatase. Nat Struct Biol 2000, 7: 1046-1050.

95. Rashid N, Imanaka H, Kanai T, Fukui T, Atomi H, Imanaka T: A novel candidate for the true fructose-1,6-bisphosphatase in archaea. I Biol Chem 2002, 277:30649-30655.

96. Sato T, Imanaka H, Rashid N, Fukui T, Atomi H, Imanaka T: Genetic evidence identifying the true gluconeogenic fructose- $1,6-$ bisphosphatase in Thermococcus kodakaraensis and other hyperthermophiles. J Bacteriol 2004, 186:5799-5807.
97. Chen L, Roberts MF: Cloning and expression of the inositol monophosphatase gene from Methanococcus jannaschii and characterization of the enzyme. Appl Environ Microbiol 1998, 64:2609-26I5.

98. Stieglitz KA, Seaton BA, Head JF, Stec B, Roberts MF: Unexpected similarity in regulation between an archaeal inositol monophosphatase/fructose bisphosphatase and chloroplast fructose bisphosphatase. Protein Sci 2003, 12:760-767.

99. Martins LO, Empadinhas N, Marugg JD, Miguel C, Ferreira C, da Costa MS, Santos H: Biosynthesis of mannosylglycerate in the thermophilic bacterium Rhodothermus marinus. Biochemical and genetic characterization of a mannosylglycerate synthase. J Biol Chem 1999, 274:35407-354I4.

100. Empadinhas N, Marugg JD, Borges N, Santos H, da Costa MS: Pathway for the synthesis of mannosylglycerate in the hyperthermophilic archaeon Pyrococcus horikoshii. Biochemical and genetic characterization of key enzymes. J Biol Chem 200I, 276:43580-43588.

I0I. Borges N, Marugg JD, Empadinhas N, da Costa MS, Santos H: Specialized roles of the two pathways for the synthesis of mannosylglycerate in osmoadaptation and thermoadaptation of Rhodothermus marinus. J Biol Chem 2004, 279:9892-9898.

102. Lehmacher A, Hensel R: Cloning, sequencing and expression of the gene encoding 2-phosphoglycerate kinase from Methanothermus fervidus. Mol Gen Genet 1994, 242: 163-168.

103. Van Alebeek GJWM, Tafazzul G, Kreuwels MJJ, Keltjens JT, Vogels GD: Cyclic 2,3-diphosphoglycerate metabolism in Methanobacterium thermoautotrophoicum $\Delta \mathbf{H}$. Arch Microbiol 1994 162:193-198.

104. Matussek K, Moritz P, Brunner N, Eckerskorn C, Hensel R: Cloning, sequencing, and expression of the gene encoding cyclic 2,3 diphosphoglycerate synthetase, the key enzyme of cyclic 2 , 3-diphosphoglycerate metabolism in Methanothermus fervidus. J Bacteriol 1998, 180:5997-6004.

105. Van Alebeek GJWM, Kreuwels MJJ, Keltjens JT, Vogels GD: Methanobacterium thermoautotrophicum $\Delta \mathbf{H}$ contains a membrane-bound cyclic 2,3-diphosphoglycerate hydrolase. Arch Microbiol 1994, 161:5 14-520.

106. Sastry MVK, Robertson DE, Moynihan A, Roberts MF: Enzymatic degradation of cyclic 2,3-diphosphoglycerate to 2,3-diphosphoglycerate in Methanobacterium thermoautotrophicum. Biochemistry 1992, $31: 2926-2935$.

107. Poolman B, Spitzer JJ, Wood JM: Bacterial osmosensing: roles of membrane structure and electrostatics in lipid-protein and protein-protein interactions. Biochim Biophys Acta 2004, 1666:88-104.

108. Baliarda A, Robert H, Jebbar M, Blanco C, Le Marrec C: Isolation and characterization of ButA, a secondary glycine betaine transport system operating in Tetragenococcus halophila. Curr Microbiol 2003, 47:347-35I.

109. Vermeulen V, Kunte HJ: Marinococcus halophilus DSM 20408T encodes two transporters for compatible solutes belonging to the betaine-carnitine-choline transporter family: identification and characterization of ectoine transporter EctM and glycine betaine transporter BetM. Extremophiles 2004, 8: $175-184$.

II0. Bayles DO, Wilkinson BJ: Osmoprotectants and cryoprotectants for Listeria monocytogenes. Lett Appl Microbiol 2000 , 30:23-27.

III. Steger R, Weinand M, Kramer R, Morbach S: LcoP, an osmoregulated betaine/ectoine uptake system from Corynebacterium glutamicum. FEBS Lett 2004, 573:155-160.

112. Proctor LM, Lai R, Gunsalus RP: The methanogenic archaeon Methanosarcina thermophila TM-I possesses a high-affinity glycine betaine transporter involved in osmotic adaptation. Appl Environ Microbiol 1997, 63:2252-2257.

113. Roessler M, Pflüger K, Flach H, Lienard T, Gottschalk G, Müller V: Identification of a salt-induced primary transporter for glycine betaine in the methanogen Methanosarcina mazei Göl. Appl Environ Microbiol 2002, 68:2133-2I39.

114. Schiefner A, Holtmann G, Diederichs K, Welte W, Bremer E: Structural basis for the binding of compatible solutes by ProX from the hyperthermophilic archaeon Archaeoglobus fulgidus. J Biol Chem 2004, 279:48270-4828I.

II5. Nagata $S$, Wang $Y B$ : Interrelation between synthesis and uptake of ectoine for the growth of the halotolerant Brevi- 
bacterium species JCM 6894 at high osmolarity. Microbios 2001 104:7-I5.

116. Grammann K, Volke A, Kunte HJ: New type of osmoregulated solute transporter identified in halophilic members of the bacteria domain: TRAP transporter TeaABC mediates uptake of ectoine and hydroxyectoine in Halomonas elongata DSM 258 I(T). J Bacteriol 2002, I 84:3078-3085

I17. Jebbar M, Sohn-Bosser L, Bremer E, Bernard T, Blanco C: Ectoineinduced proteins in Sinorhizobium meliloti include an ectoine ABC-type transporter involved in osmoprotection and ectoine catabolism. J Bacteriol 2005, 187: | 293-1304.

1 18. Kokoeva MV, Storch K-F, Klein C, Oesterhelt D: A novel mode of sensory transduction in archaea: binding protein-mediated chemotaxis towards osmoprotectants and amino acids. $E M B O$ ] 2002, 2 I:23 I 2-2322.

119. Neelon K, Roberts MF: Organic Solute Pools of Halobacterium NRC-I: Dependence on Growth Conditions and Response to Stress. Extremophiles 2005 in press.

120. Zhou Y, Morais-Cabral JH, Kaufman A, MacKinnon R: Chemistry of ion coordination and hydration revealed by a $\mathrm{K}^{+}$channel-Fab complex at 2.0Å resolution. Nature 200I, 4| 4:43-48.

121. Jiang Y, Lee A, Chen J, Ruta V, Cadene M, Chait BT, MacKinnon R: Xray structure of a voltage-dependent $\mathrm{K}^{+}$channel. Nature 2003 , 423:33-4I

122. Kraegeloh A, Amendt $B$, Kunte HJ: Potassium transport in a halophilic member of the Bacteria domain: identification and characterization of the $\mathrm{K}^{+}$uptake systems TrkH and Trkl from Halomonas elongata DSM 258IT. J Bacteriol 2004, 187:1036-1043.

123. Edwards MD, Booth IR, Miller S: Gating the bacvterial mechanosensitive channels: MscS a new paradigm. Curr Opin Microbiol 2004, 7:163-167.

124. Blount P, Moe PC: Bacterial mechanosensitive channels: integrating physiology, structure and function. Trends Microbiol 1999, 7:420-424.

125. Poolman B, Blount P, Folgering JHA, Friesen RHE, Moe PC, van der Heide $\mathrm{T}$ : How do membrane proteins sense water stress? Molec Microbiol 2002, 44:889-902.

126. Perlman DF, Goldstein L: Organic osmolyte channels in cell volume regulation in vertebrates. Exp Zool 1999, 283:725-733.

127. Liu Y, Bolen DW: The peptide backbone plays a dominant role in protein stabilization by naturally occurring osmolytes. Biochemistry 1995, 34: 12884-1289|.

128. Timasheff SN: Protein-solvent preferential interactions, protein hydration, and the modulation of biochemical reactions by solvent components. Proc Natl Acad Sci USA 2002, 99:9721-9726.

129. Timasheff SN: Protein hydration, thermodynamic binding, and preferential hydration. Biochemistry 2002, 4 I: | $3473-13482$.

130. Plaza di Pino IM, Sanchez-Ruiz JM: An osmolyte effect on the heat capacity change for protein folding. Biochemistry 1995, 34:862I-8630.

13I. Bolen DW, Baskakov IV: The osmophobic effect: natural selection of a thermodynamic force in protein folding. J Mol Biol 200I, 3 1 0:955-963.

132. Cioni P, Bramanti E, Strambini GB: Effects of sucrose on the internal dynamics of azurin. Biophys $J 2005$ in press.

133. Kunz W, Henle J, Ninham BW: About the science of the effect of salts: Franz Hofmeister's historical papers. Curr Opin Coll Interface Sci 2004, 9:19-37.

134. Baldwin RL: How Hofmeister interactions affect protein stability. Biophys ] 1996, 7I:2056-2063.

135. Yancey PH, Clark ME, Hand SC, Bowlus RD, Somero GN: Living with water stress: evolution of osmolyte systems. Science 1982, 217:1214-1222.

136. Collins KD, Washabaugh MW: The Hofmeister effect and the behavior of water at interfaces. I Biol Chem 1985, 18:323-422.

137. Collins KD: Ions from the Hofmeister series and osmolytes: effects on proteins in solution and in the crystallization process. Methods 2004, 34:300-3II.

138. Wiggins PM: Role of water in some biological processes. Microbiol $\operatorname{Rev}$ 1990, 54:432-449.

139. Minton AP: Effects of excluded surface area and adsorbate clustering on surface adsorption of proteins I. Equilibrium models. Biophys Chem 2000, 86:239-247.
140. Minton AP: Effects of excluded surface area and adsorbate clustering on surface adsorption of proteins. II. Kinetic models. Biophys J 200I, 80:164I-1648.

I4I. Hall D, Minton AP: Macromolecular crowding: qualitative and semiquantitative successes, quantitative challenges. Biochim Biophys Acta 2003, 1649:127-139.

142. Robinson CR, Sligar SG: Hydrostatic and osmotic pressure as tools to study macromolecular recognition. Methods Enzymol 1995, 259:395-427.

143. Hummer G, Garde S, Garcia AE, Paulaitis ME, Pratt LR: The pressure dependence of hydrophobic interactions is consistent with the observed pressure denaturation of proteins. Proc Natl Acad Sci USA 1998, 95:1552-1555.

144. Diamant S, Eliahu N, Rosenthal D, Goloubinoff P: Chemical chaperones regulate molecular chaperones in vitro and in cells under combined salt and heat stresses. J Biol Chem 200I, 276:39586-3959l.

145. Faria TQ, Lima JC, Bastos M, Macanita AL, Santos H: Protein stabilization by osmolytes from hyperthermophiles: effect of mannosylglycerate on the thermal unfolding of recombinant nuclease a from Staphylococcus aureus studied by picosecond time-resolved fluorescence and calorimetry. J Biol Chem 2004, 279:48680-4869l.

146. Ratnaparkhi GS, Varadarajan R: Osmolytes stabilize ribonuclease $S$ by stabilizing its fragments $S$ protein and $S$ peptide to compact folding-competent states. I Biol Chem 200I, 276:28789-2898

147. Singh R, Haque I, Ahmad F: Counteracting osmoyte trimethylamine $\mathbf{N}$-oxide destabilizes proteins at $\mathbf{p H}$ below its $\mathbf{p K}_{\mathbf{a}}$. $J$ Biol Chem 2005, 280: I I035-I I 042.

148. Gahl RF, Narayan M, Xu G, Scheraga HA: Trimethylamine-Noxide modulates the reductive unfolding of onconase. Biochem Biophys Res Commun 2004, 325:707-710.

149. Mandal AK, Samaddar S, Banerjee R, Lahiri S, Bahttacharyya A, Roy S: Glutamate counteracts the denaturing effect of urea through its effect on the denatured state. J Biol Chem 2003, 278:36077-36084.

150. Pais TM, Lamosa P, dos Santos W, Legall W, Turner DL, Santos H: Structural determinants of protein stabilization by solutes. The important of the hairpin loop in rubredoxins. FEBS Lett 2005, 272:999-10II.

15I. Celinski SA, Scholtz JM: Osmolyte effects on helix formation in peptides and the stability of coiled-coils. Protein Sci 2002, I I:2048-205I.

152. Butler SL, Falke J]: Effects of protein stabilizing agents on thermal backbone motions: a disulfide trapping study. Biochemistry 1996, 35:40595-40600.

153. Foord RL, Leatherbarrow RJ: Effects of osmolytes on the exchange rates of backbone amide hydrogens in proteins. Biochemistry 1998, 37:2969-2978.

154. Qu Y, Bolen W: Hydrogen exchange kinetics of Rnase $A$ and the urea:TMAO paradigm. Biochemistry 2003, 42:5837-5849.

155. Kim YS, Jones LS, Dong A, Kendrick BS, Chang BS, Manning MC, Randolph TW, Carpenter JF: Effects of sucrose on conformational equilibria and fluctuations within the native-site ensemble of proteins. Protein Sci 2003, 12:1252-1261.

156. Wright DB, Banks DD, Lohman JR, Hilsenbeck JL, Gloss LM: The effect of salts on the activity and stability of Escherichia coli and Haloferax volcanii dihydrofolate reductases. I Mol Biol 2002, 323:327-344.

157. Rees WA, Yager TD, Korte J, von Hippel PH: Betaine can eliminate the base pair composition dependence of DNA melting. Biochemistry 1993, 32:137-144.

158. Henke W, Herdel K, Jung K, Schnorr D, Loening SA: Betaine improves the PCR amplification of GC-rich DNA sequences. Nucl Acids Res 1997, 25:3957-3958.

159. Malin G, lakobashvili R, Lapidot A: Effect of tetrahydropyrimidine derivatives on protein-nucleic acids interaction. Type II restriction endonucleases as a model system. J Biol Chem I999, 274:6920-6929.

160. Sauer T, Galinski EA: Bacterial milking: A novel bioprocess for production of compatible solutes. Biotechnol Bioeng 1998, 57:306-3I3

16I. Barth S, Huhn M, Matthey B, Klimka A, Galinski EA, Engert A: Compatible-solute-supported periplasmic expression of func- 
tional recombinant proteins under stress conditions. Appl Environ Microbiol 2000, 66: I572-1579.

162. Arora A, Ha C, Park CB: Inhibition of insulin amyloid formation by small stress molecules. FEBS Lett 2004, 564:12I-125.

163. Schnoor M, Voss P, Cullen P, Boking T, Galla HJ, Galinski EA, Lorkowski S: Characterization of the synthetic compatible solute homoectoine as a potent PCR enhancer. Biochem Biophys Res Commun 2004, 322:867-872.

164. Cleland D, Krader P, McCree C, Tang J, Emerson D: Glycine betaine as a cryoprotectant for prokaryotes. I Microbiol Methods 2004, 58:3।-38.

165. Bünger J, Driller H: Ectoin: An Effective Natural Substance to Prevent UVA-Induced Premature Photoaging. Skin Pharmacol Physiol 2004, 17:232-237.

166. Alia HH, Sakamoto A, Murata N: Enhancement of the tolerance of Arabidopsis to high temperatures by genetic engineering of the synthesis of glycinebetaine. Plant J 1998, 16:155-161.

167. Holmstrom KO, Somersalo S, Mandal A, Palva TE, Welin B: Improved tolerance to salinity and low temperature in transgenic tobacco producing glycine betaine. J Exp Bot 2000, 5I:177-185.

168. Nakayama H, Yoshida K, Ono H, Murooka Y, Shinmyo A: Ectoine, the compatible solute of Halomonas elongata, confers hyperosmotic tolerance in cultured tobacco cells. Plant Physiol 2000, I 22:1239-1247.

169. Rontein D, Basset G, Hanson AD: Metabolic engineering of osmoprotectant accumulation in plants. Metab Eng 2002, 4:49-56.

170. Brown AD: Compatible solutes and extreme water stress in eukaryotic micro-organisms. Adv Microb Physiol 1978, 17:181-242.

Publish with Bio Med Central and every scientist can read your work free of charge

"BioMed Central will be the most significant development for disseminating the results of biomedical research in our lifetime. "

Sir Paul Nurse, Cancer Research UK

Your research papers will be:

- available free of charge to the entire biomedical community

- peer reviewed and published immediately upon acceptance

- cited in PubMed and archived on PubMed Central

- yours - you keep the copyright

Submit your manuscript here:

http://www.biomedcentral.com/info/publishing_adv.asp
BiolMedcentral 